\title{
التباين المكاني للمعوقين في ممانظة واسط
}

م.د. صباح وهب عبد كلية التربية/ جامعة واسط ومبه

الاقدمهة

الحمد الله و الصلاة والسلام على رسول الله و على آله وصحبه وبعد، إن الاعاقة بشتى أنو اعها ودرجاتها

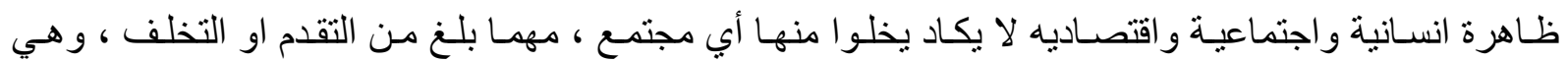
مشكلة تلقي بأثر ها على الدول و الأفراد، إذ نوجب عليهم مسئولية كبيرة في تأهيل المعـاق و العنايـة بـه من حيث التعليم والتدريب وتوفير الخدمات والاحتياجـات الضـرورية لـه، والاهتمـام بالوقايـة والعـلاج، باعتبـاره فرد في بـ في المجتمع له حقوق حسب الثـرائع والأنظمة و القو انين، وترتبط هذه المشكلة ارتباطا وثنقا بمدى انتشـار الوعي

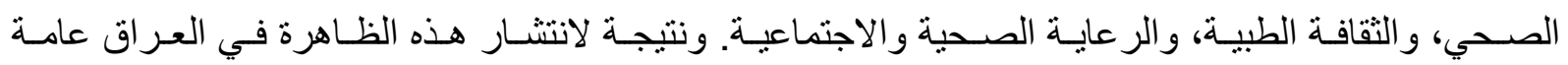
و وحافظة واسط خاصـة، التي تم در استها مـن البـاحثين من مختلف الفئسات والاختصاصـات الطبيـة والنفسية، وجدت من الضروري تناو لها من وجهة جغر افية، لذلك جاءت مشكلة البحث بصيغة الاسئلة الاتية: 1 - ما هي العوامل المؤثرة في التباين المكاني للمعاقين في محافظة واسط . r- ما هي اسباب الاعاقة وأنو اعها. r- ما هي الاثار المترتبة من انتشار ظاهرة الاعاقة. ع- ما هي ابرز المشاكل التي يعاني منها المعاقين.

\section{فرضية البمث}

فهي تتمثل في ان هناك مجمو عة من العو امل تؤثر في التباين المكاني للمعاقين في محافظـة واسط، فضـلا عن وجود الكثير من الاسباب التي تؤدي الى الاعاقة، وكذلك هناك انواع عديدة للإعاقة، بالإضـافة الى الاثار التي تتتج من جر اء انتشار ظاهرة الاعاقة، اضافة الى وجود الكثير من المشاكل التي يعاني منها المعاقين خـلال حياتهم الاعتيادية. الهمية البحث: تكمن من خلال اعتبار الثخص المعاق هو فرد في المجتمع ولديه حقوق يجب توفير ها ليتمكن من ممارسة حياته بالثكل الطبيعي اسوة بأقر انه.

حدود البحث: تتمثل الحدود المكانية في مر اكز الاقضية ضمن محافظة واسط ، والتي بلغت ست مر اكز وهي (مركز قضاء الكوت و الصويرة و العزيزية والحي و النعمانية وبدرة) * ، اما الحدود الزمانية فقد حددت بالعام (

خطـة البحث وتتظيمهـ: تتطلب در اسـة البحث جمع المعلومـات و البيانـات الخاصـة بأعداد السكان المعـقين في محافظة واسط وذلك من خلال استمارة استبيان اعدت لهذا الغرض ، وبعض السجلات الغير منشورة لبعض الدو ائر الرسمية وتحضير الخر ائط الخاصة بمنطقة الدراسة بالإضـافة الى جمع المعلومـات من التقارير والكتب و البحوث و الدر اسات (الاطاريح والرسائل) المتعلقة بالموضوع. حيث يتضمن البحث ثمان محاور رئيسة هي: 
المحور الاول: مفهوم الاعاقة .

المحور الثاني: التوزيع الجغر افي للمعاقين المحور الثالث: التركيب العمري والنوعي للمعاقين المحور الرابع: العو امل المؤثرة في التباين المكاني للمعوقين. المحور الخامس: انواع الاعاقة. المحور السادس: اسباب الاعاقة المحور السابع: المشاكل التي يعاني منها المعوقين. المحور الثامن: الاثار الناتجة من انتشار ظاهرة الاعاقة.

\section{دراسات سابقة}

لاى مر اجعة الباحثة لأدبيات الدراسات السابقة في مجال المعاقين ،تبين وجود كم من الدراسـات تناولت هذا الجانب من منظور نفسي فقط ، وكانت بعض هذه الدراسـات قد نجحت في التوفيق بين الجانب النفسي و الاجتماعي للمعاق للوصول إلى تحليل مكتمل. وفيما يأتي سيتم التطرق لبعض الدراسـات التي جمعت عن هذا الموضوع .

دراسـة (لبيـة أبو شـريف، 1991) (') فقد هدفت إلى التعرف على الأنماط السلوكية غير التكيفية المرتبطـة بإيقاع الإساءة البدنية على المعوقين عقلياً الملتحقين بمدارس التربية الخاصة ومر اكز ها في عمان، والى معرفة الأنماط السلوكية غير التكيفية التي تميز بين المعوقين عقلياً المسـاء إليهم المعوقين عقلياً غير المسـاء إليهح ، بالإضافة إلى معرفة مدى ارتباط هذه الأنماط بكل من متغيري الجنس و العمر.

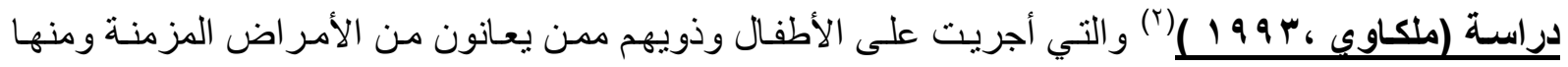

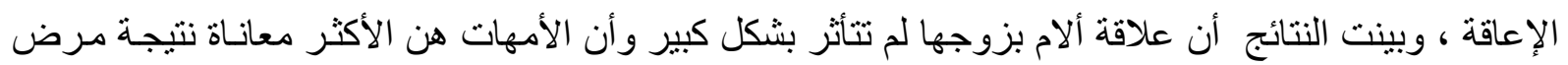
طفلهم حيث تعاني معظمهن من الاكتئاب نتيجة مصاحبة طفلها خلال مسيرة العلاج. ودلت النتائج ايضاً أن اغلب المحيطين بالأسرة ينظرون إلى الطفل وأسرته نظرة شفقة وحزن ـأخير اً أكدت الدراسـة أن أسرة الطفل لم تبتعد عن الاختلاط بالناس بل إن غالبية الأمهات يصطحبن أطفالهن خارجاً أمام الناس .

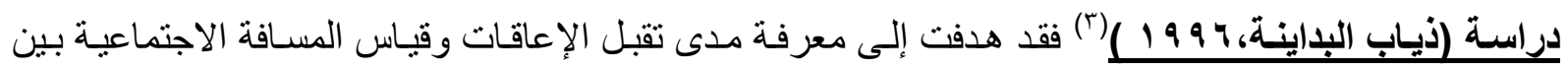
المعـقين في المجتمـع الأردني. وهدفت ايضـاً إلى معرفـة اثر متغيـر الجنس و المستوى الأكاديمي في النظرة

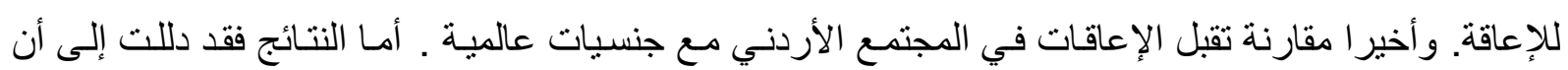
هنالك عدم تقبل للإعاقات بشكل عـام ، وان هنـاك فروق ذات دلالـة إحصـائية في تقبل الإعاقـات. كمـا تبين أن الإعاقـة الخفيفة(السكري، التهـاب المفاصـل) قد لاقت قبـو لاً أفضـل مـن الإعاقـات الأخـرى. كمـا أن الإعاقـات الظاهرة (التخلف العقلي، المرض النفسي، الثلل الدماغي) كانت أكثر الإعاقات رفضاً لعينة الدراسة.

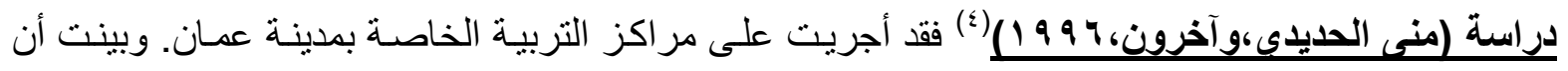

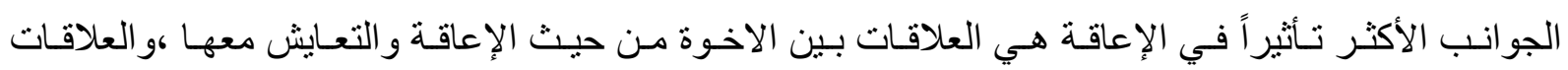
الاجتماعية والوضع العام للو الدين. إضافة إلى التحديات والصعوبات التي تواجه الأسرة بشكل عام ،و عدم توفر 
الخدمات التي تشكل مصدر ضغط وتأثنير كبيرين على الأسرة ، علاوة على التنقل من طبيب لآخر بحثناً عن

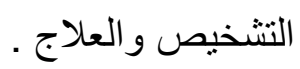

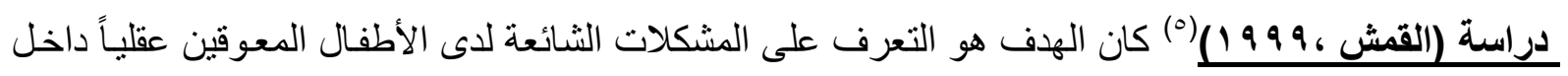

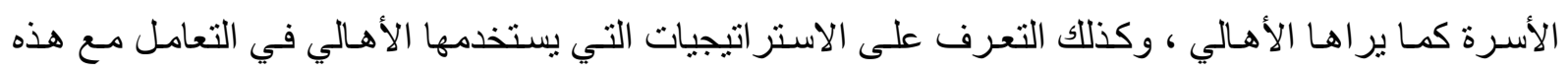
المشكلات ـ وقد توصلت الدراسـة إلى عدة نتائج نذكر منهـا ، أن اكثر المشكلات شيو عاً لدى هؤلاء الأطفال الحركة الزائدة ، ثم الانسحاب الاجتماعي فالسلوك النمطي ثم العدوان ثم إيذاء الذات ـ

اولا: مفهوم الاعاقة:

لغة واصطلاحا: المعـاق والمعوق لفظـان يطلقان على الانسـان الذي اصيب بعاهـة خلقيـة او غير خلقيـة اثرت في قدر اته ، ومن الناس من يستخدم لفظ (المعاق) ومنهم من يستخدم لفظ (المعوق). امـا المعاق لغـة: فهو اسم المفعول من الفعل (أعاق)، و الفعل أعاق هو مزيد الثناثي عاق، جاء في معاجم اللغة (عاقه، يعوقه، عَوقاً ): صرفه وحبسه (؟) ، اما المعوق لغة :- هو اسم المفعول من عوق، واسم الفاعل من عوق: معوق ، وفي التنزيل

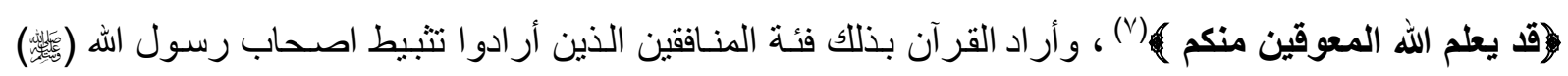
عن الجهاد. ويرى البعض ان استخدام لفظ (المعوق) ، اولى من استخدام لفظ ( المعـاق) لأن الفعل عوق تدل الزيادة فيه على التكثير و المبالغة ، ولما كان المعوق صاحب عاهة دائمة فأن لفظة المعوق ادق في اطلاقها عليه ، في حين ان لفظ المعاق تدل على من تحدث لـه اعاقة مؤقتة وليست دائمة:(^). امـا المعاق (المعوق) اصطلاحاً فهو الثخص العاجز كليا عن ضمان حياة شخصية ، أو اجتماعية أو طبيعية نتيجة نقص خلقي وغير خلقي ، في

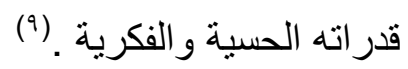

\section{تعريف الاعاقة}

انها إصابة عضوية أو عقلية تحد أو تقلل بشكل كبير من أنشطة الفرد في أكثر المهار ات الحياتيـة . فالفرد الذي يعاني من إصابة تحول دون قيامه بواحدة أو أكثر من الأنشطة والمهار ات الحياتيـة، وهو في نفس الوقت بحاجة إلى أجهزة تساعده في التنقل والحركة أو أنه يعتمد على الآخرين لتأدية اعماله اليومية، فإنه يصنف على أنه يعاني من إعاقة شديدة وتشتمل الإعاقة على تلك الإصابات المتعلقة بالحو اس أو الأعضاء أو الجانب العقلي ، وقد تكون جزئية أو بسيطة أو كلية. (·)

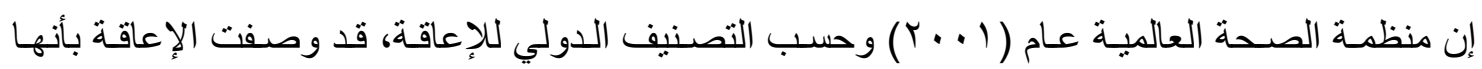
وجـود صـوبة في القيـام بعمل أساسـي بالنسبة لنشـاط الثـص اليومي، كالاعتنـاء بنفسـه، او القبـام بالنشـاط الاجتماعي والاقتصادي الذي ينماثـى مع عمر الثخص، وجنسه ودوره الطبيعي في المجتمع. أو هو حالة من

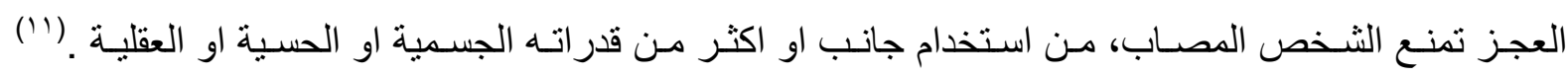
و عرف مؤتمر السـلام العـالمي والتأهيل (المعوق) بأنه كل فرد يختلف عمن يطلق عليه لفظ سوي او عـادي جسميا او عقليا او نفسيا او اجتماعيا الى الحد الذي يستوجب اجر اء عمليات تأهيلية خاصـة لله

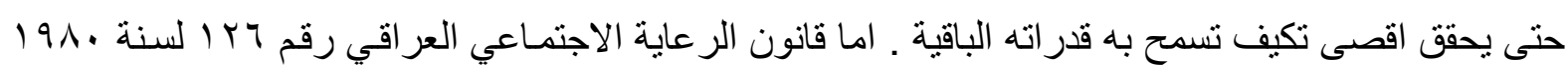




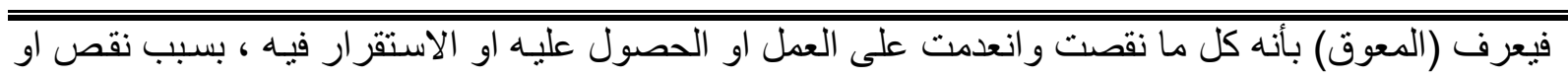

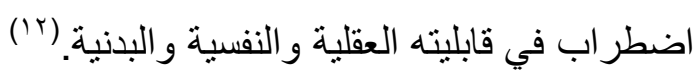

وتعتبر ظـاهرة الإعاقـة مـن الظـواهر المألوفـة ، وتلقـى الاهتمـام مـن جانـب المجتمعـات والمؤسسـات و المنظمات الدولية. اذ ركز مفهوم الإعاقة على قصور أداء الفرد ضـمن السياق الاجتماعي الذي يعيش فيه،

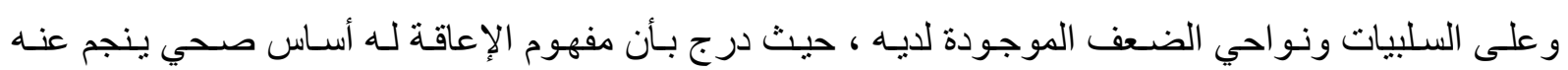
ضعف في وظائف الجسد وبنيته، ومحددات النشاط، وتقييد مشاركة الفرد المجتمعية في سياق العوامل الثخصية و البيئية.وفيما بعد تطور مفهوم الإعاقة ليركز على التفاعل المنتظم بين الفرد والبيئة التي يعيش فيها، وتقييم الثخص المعوق ضمن البيئة التي ينتمي إليها والأخذ بالاعتبار أن تقديم الدعم الفردي له سوف يؤدي إلى تحسين أدائه الوظيفي.

قد تشكل مفهوم الإعاقة الحالي خلال العقود الأخيرة نتيجة تطور الوعي المجتمعي نحو الإعاقة ، وتتمثل العو امل الرئيسية التي أدت إلى هذا التطور بما يأتي: أ) البحث عن المضامين الاجتماعية للمرض وأثره الكبير على المجتمع والاتجاهات والأدوار والسياسـات التي أصبح بدرك من خلالها الفرد الاضطر ابات الصحية. ب) وضوح الفارق التاريخي بين المسبيات البيولوجية والاجنماعية المؤدية للإعاقة. ت) الاعتر اف بتعدد أبعاد الأداء الإنساني واختلافها. وبسبب هذه العو امل، فإن مفهوم الإعاقة قد تطور من السمات أو الخصائص المتمركزة حول الفرد (التي

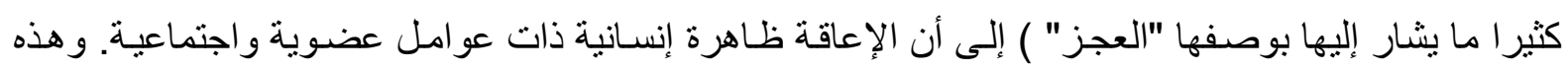
العو امل العضوية و الاجتماعية تؤدي إلى القصسور الوظيفي وتنعكس على شكل ضـعف في الأداء الثخصسي

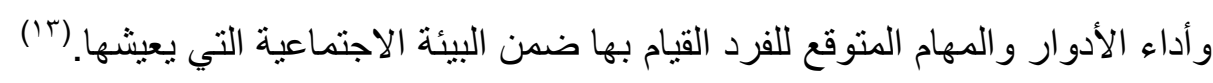

\section{ثانيا: التوزيج الجغراني المعوقين}

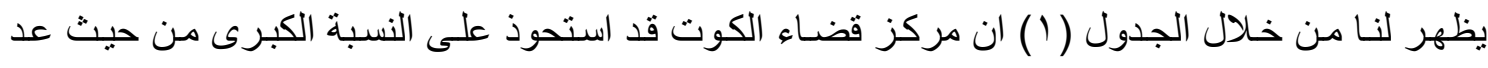

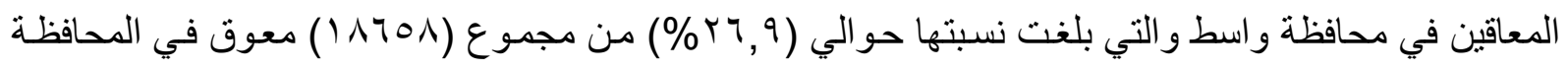
لعـام \991 م ، نتيجـة للحروب التي مر بها العراق خـلال السنوات التي سبقت هذا العـام ، كذلك بسبب كبر

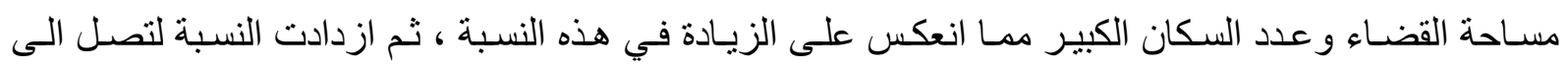

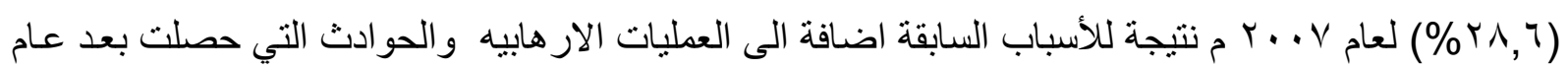

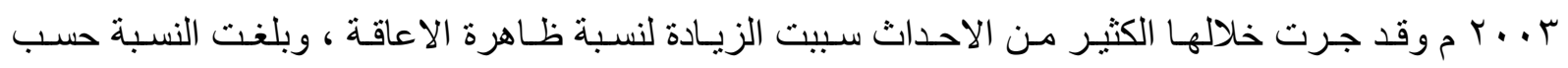

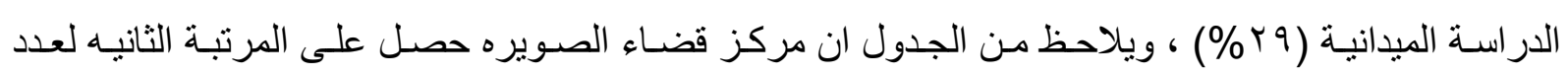

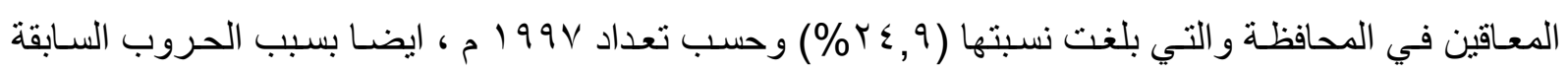

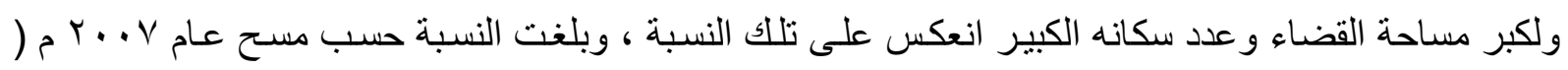

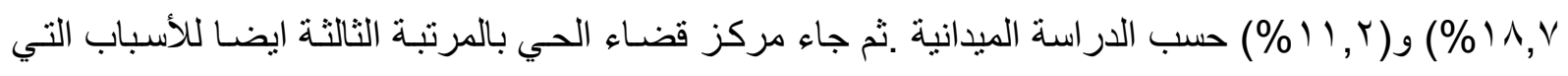




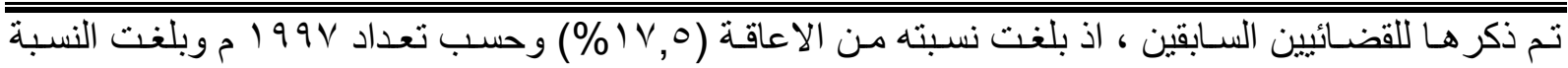

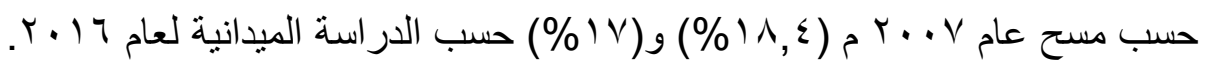

تبين من الجدول ايضـا ان كل من مركز قضـاء بدرة والنعمانيـة والعزيزيـه قد جـاءت بالمر اتب الثثلاثة

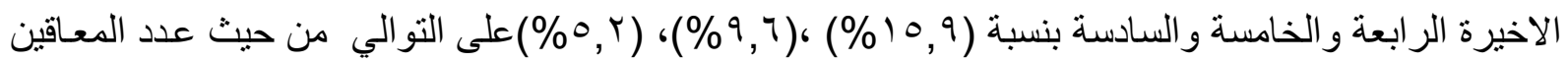
، وذللك يعود الى صغر المساحة وبالتالي قلة عدد السكان مما انعكس على قلة اعداد المعاقين . جدول (1) عدد السكان المعوقين في محافظة واسط

\begin{tabular}{|c|c|c|c|c|c|c|}
\hline$\%$ & الالدراسية & $\%$ & $r \cdot r v$ & $\%$ & $199 V$ & الوحدة الإدارية \\
\hline rq & $1 \leqslant 0$ & $r \wedge, \gamma$ & $\wedge 9 \ldots$ & rq,9 & 0.10 & مركز قضاء الكوت \\
\hline $10, r$ & 87 & $11, \wedge$ & rצAr & 9,7 & 1899 & مركز قضاءالنعمانية \\
\hline IV & 10 & $11, \varepsilon$ & OVMI & $1 V, 0$ & rrVE & مركز قضاء الحي \\
\hline 17,1 & $\Lambda \varepsilon$ & $1 r, \Lambda$ & $r q 9 r$ & 10,9 & rqA1 & مركز قضاء بارة \\
\hline $11, r$ & 09 & $1 \wedge, v$ & $0 \wedge \cdot 1$ & $r \leqslant, q$ & $\sum Y 0 Y$ & مركز قضاءالصويرة \\
\hline $1 \cdot, \wedge$ & $0 \leqslant$ & $9, V$ & rq१Y & $0, r$ & 9 qः. & مركز قضاعالعزيزية \\
\hline$\% 1 \ldots$ & $0 \ldots$ & $\% 1 \ldots$ & 11.99 & $\% 1 \ldots$ & $1 \wedge 701$ & المجموع \\
\hline
\end{tabular}

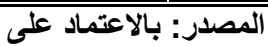

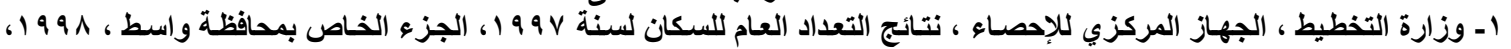

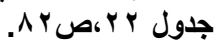

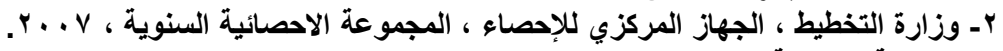

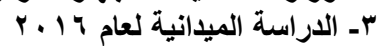

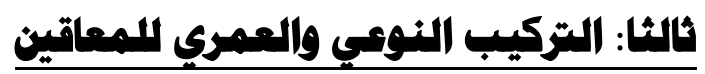

تختلف نسبة المعاقين بين الذكور والإنـاث حسب السن اختلافا جو هريـا والتي تتصل بدور ها بالحالة الصحية للسكان فضلا عن طبيعة العمل الذي يمارسه الفرد حيث تكون معدلات الذكور اعلى مما هي للإنـاث ، فالذكور يزاولون الاعمال الخطرة التي تتطلب جهدا كما انهم اكثر انتقالا في المسافات الطويلة من الاناث سواء في السعي وراء العمل او الاستجمام فيكونون اكثر عرضة للحوادث المختلفة ، كما انهم العامل الرئيسي الذي يعتمد عليه في الحرب ، لذا نال التركيب النوعي و العمري اهتمام الباحثين و الدارسين.(؛ ()

\section{النزكيب النوعي للمعاقين}

ان دراسة التركيب النوعي ذات اهمية علمية كبيرة فأعداد الذكور وأعداد الانـاث ونسبة كل منهمـا من المجتمع السكاني لها نتائجها الاقتصادية والاجتماعية ولعل تأثثر اتها في قوة العمل ومعدلات المو اليد والتوزيع

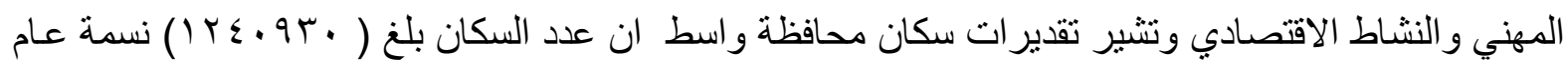

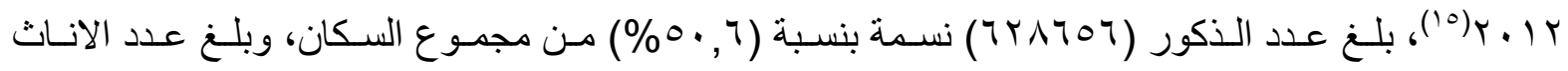

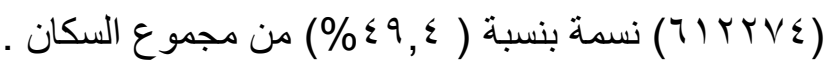
يتضح من الجدول (Y) و الخريطة ( () ان نسبة المعاقين بين الذكور اعلى من الاناث ، اذ بلغت نسبة

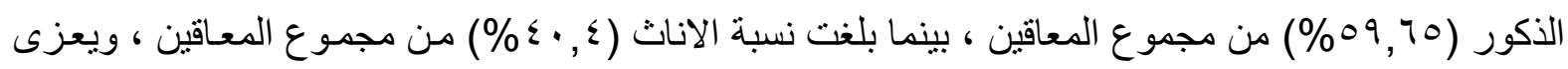
ذللك الى كثرة حوادث الانفجار ات والطلق الناري الذي يتعرض لها الذكور اعلى من الانـاث فضـلا عن حوادث الار هاب اسهمت بشكل كبير في اعاقة الذكور حيث كثرة السفر والانتقال ، اضافة الى الحوادث المروريـة التي ادت الى ارتفاع نسبة المعاقين من الذكور . 


\begin{tabular}{|c|c|c|c|c|c|c|}
\hline$\%$ & المجموع & $\%$ & اناث & $\%$ & ذكور & الوحدة الإداريـة \\
\hline$\% 1 \ldots$ & $1 \leqslant 0$ & $r q, r$ & $\Delta V$ & $7 \cdot, \mathrm{V}$ & $\Lambda \wedge$ & مركز قضاء الكوت \\
\hline$\%$ & V7 & $\leqslant 0,9$ & $r r$ & 07,7 & $\varepsilon r$ & مركز قضاء|لنعماتية \\
\hline$\%$ & 10 & 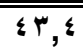 & rq & $0 \leqslant, 1$ & $\varepsilon 7$ & مركز قضاء الحي \\
\hline$\%$ \%।.. & $\overline{\Lambda \varepsilon}$ & 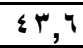 & $r \wedge$ & $0 \leqslant, \wedge$ & $\varepsilon 7$ & مركز قضاء بدرة \\
\hline$\%$ & 07 & $\overline{Y 1, \varepsilon}$ & Ir & $\overline{\vee \wedge, 7}$ & $\varepsilon \varepsilon$ & مركز قضاءالصويرة \\
\hline \%1... & $0 \leq$ & $\varepsilon 0, r$ & $r r$ & $0 \vee, \varepsilon$ & $\mu_{1}$ & مركز قضاءالعزيزية \\
\hline$\%$ & $0 \ldots$ & $\varepsilon \cdot, \varepsilon$ & $r \cdot r$ & 09,7 & rqA & المجموع \\
\hline
\end{tabular}

الثزكيب العمري الامعاقين

التركيب العمري للسكان هو توزيع السكان حسب فئات الأعمـار المختلفة، أمـا الفئات العمريـة الثثلاث الرئيسة فهي:(أقل من 10 سنة) و هم صغار السن، أو الأطفال،( 10 ـ ؟ آنـة)، وهم الثباب أو الأشخاص

$$
\text { في سن الإنتاج، (07 سنة فأكثر)، وهم كبار السن، أو الثيوخ. }
$$

يتضح من الجدول (r) ان هناللك تباين في النسب المئوية لكل فئسة عمريـة من مجموع المعاقين، اذ تبين

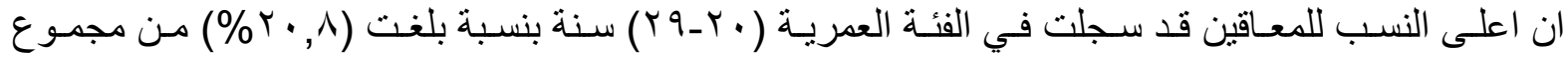

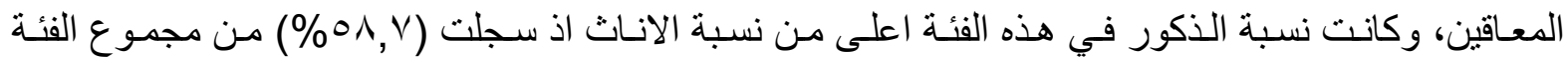

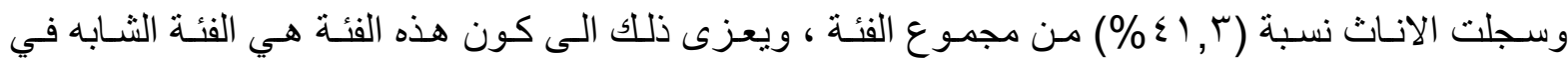
المحافظة وهي الفئة العاملة و النثيطة والتي تكون معرضة لمختلف الحوادث ، تليها الفئة العمريـة (0ـ9) سنة

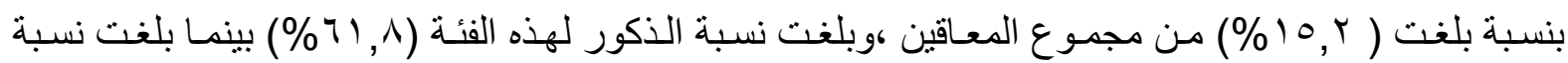
الاناث (0, ب ب)من مجموع الفئة ويعود السبب في ذلك اللى كون الذكور اكثر حركة من الاناث و اغلبهم يخرج للعـب خـارج المنزل و التعـرض للحـوادث اضـافة الـى الاسباب الولاديـة حيث يكون الـذكور اقل مناعـة مـن

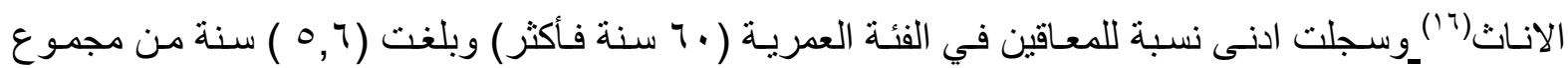

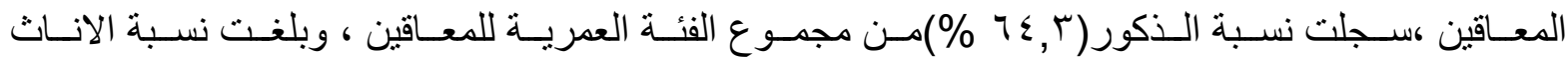
(\% من مجموع الفئة العمرية للمعاقين نتيجة لكون هذه الفئة هي الفئة الاكبر سناً في المحافظة ولكونها قليلة العمل و الحركة وان اصابتها بالعوق يعود اما بسبب اصابتها منذ الو لادة او تعرضها لحادث خلال مسيرة حياتها، وتوز عت بقية النسب بين الفئات العمرية الاخرى . جدول (r) التركيب العمري للمعوقين في محافظة واسط

\begin{tabular}{|c|c|c|c|c|c|c|}
\hline$\%$ & المجموع & $\%$ & اناث & $\%$ & ذكور & الفئات العمرية \\
\hline 14,7 & 71 & $\sum 1, r$ & $r \wedge$ & $\overline{\bullet \wedge, \wedge}$ & $\varepsilon$ & $\varepsilon=$ \\
\hline $10, Y$ & 87 & $\overline{r \Lambda, r}$ & rq & $\overline{71, \wedge}$ & $\varepsilon V$ & 9.0 \\
\hline 14 & 70 & $\varepsilon q, r$ & $\overline{r r}$ & $0 \cdot, \wedge$ & $r r$ & $19-1$. \\
\hline$r \cdot, \Lambda$ & $1 \cdot \varepsilon$ & $\varepsilon 1, r$ & $\varepsilon r$ & $\Delta \wedge, V$ & 71 & rq-Y. \\
\hline $1 \cdot, 7$ & or & $\varepsilon 0, r$ & $r \varepsilon$ & $0 \leqslant, V$ & rq & rq-r. \\
\hline $9, \xi$ & $\varepsilon V$ & $\varepsilon r, 0$ & r. & 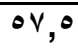 & $r V$ & $\varepsilon 9-\varepsilon$. \\
\hline 11,1 & 09 & $r v, 1$ & 17 & $\overline{V Y, q}$ & $\varepsilon r$ & 09.0. \\
\hline 0,7 & $r \wedge$ & $r \Delta, V$ & 1. & $7 \leqslant, r$ & 11 & • 7 سنة فَأكثر \\
\hline$\% 1 \ldots$ & $0 \ldots$ & $\varepsilon \cdot, \varepsilon$ & $r \cdot r$ & 09,7 & rq1 & المجموع \\
\hline
\end{tabular}

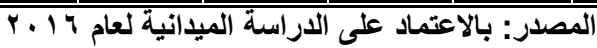




\section{رابعا: العواهل الموثرة في التباين الكاني للمعوقين}

للعو امـل الجغر افيـة سـواء كانـت طبيعيـة او بشـرية تـأثثيرات على المعوقين ، اذ مـن المككن ان تـؤثر العوامل الطبيعية ولكن بنسبة بسيطة جداً، اذ تؤدي حوادث السير والتي تزيد خلال فصل الثتاء الى حدوث البعض من حالات العوق ، بالإضـافة الى صعوبة انتقال الاشخاص المعوقين من مكان الى اخر اثنـاء سقوط الامطـار وزيـادة كميـات الطين و الأوحسال في شـوارع المحافظـة، التـي تعـاني من شبكة طرق أغلبهـا رديئة ومعظمها طرق ترابية غير معبدة ، بالإضـافة الى زيـادة التشنجات و التقلصـات والأوجـاع بسبب الحرارة او

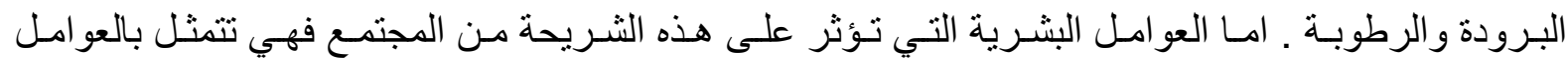
الاقتصادية و الاجتماعية و الصحية والثقافية ـ وتعمل هذه العو امل المرتبطة بـالو عي الصحي و الثقافي و المستوى الاجتماعي على زيـادة أو خفض نسبة الإعاقـة في المجتمع ، وتجمـع الدراسـات في هذا الموضـوع انـه تصبح العلاقة عكسية بين زيادة الوعي الصحي و الثقافي والاجتمـاعي وقلة نسبة المعوقين بـالمجتمع و العكس صحيح ولذا فليس من المستغرب إن تزداد نسبة المعوقين في الدول النامية مقارنة بالدول المتقدمة. و هنالك علاقة بين نسبة السكان المعوقين من خـلال ( العمر، النوع، الحالة الزواجيـة ، عدد الاطفال، نوع الوظيفة ، الحالة التعليمية، نوع أقرب مؤسسـة صحية ، مستوى دخل الاسرة ، نوع الصـرف الصحي ، محل الاقامة ( حضر/ ريف) ، نوعية السكن ، فضلاً عن التلوث البيئي و عامل الحروب والحصسار الاقتصسادي وما سببه من تدمسير للبيئة و السكان إذ تساعد هذه العوامل على زيادة نسبة المعوقين وتباينها من مكان إلى آخر بحسب تباين هذه العوامل. وسـأتناول البعض من هذه العو امل منها ( مستوى الدخل ، المستوى التعليمي ، نوعيـة السكن ، المؤسسـات الصحية ، محل الاقامـة ) باعتبار هـا اكثر العو امـل تـأثير آ في زيـادة وخفض نسبة المعوقين ، ولدر اسة تأثثير هذه العوامل تم الاستعانة بالوسـئل الاحصـائية ، واستخدام معامل ارتباط سبيرمان للارتب* ولبعض العو امل فقط.

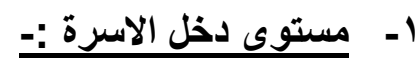

يـؤثر انخفاض مستوى دخل الفرد في نوعية الغذاء الذي يستطيع الفرد الحصول عليه ويشكل عـاملا رئيسياً في اعاقة الأطفال و الكبار على السواء لذلك يعدّ الدخل هو المؤشر الأول والأسـاس المعتمد لقياس حالة الفقر (') ،إذ عرفت الأمم المتحدة الفقر بأنـه الحرمـان من بعض حاجـات الحياة الأساسية مثنل الغذاء و المـأوى

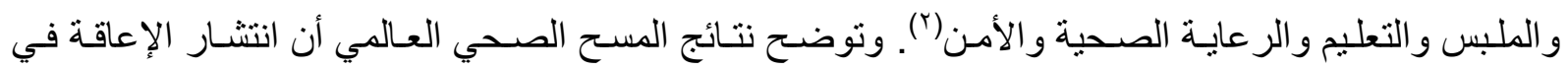
البلدان منخفضة الدخل أعلى منه في البلدان مرتفعة الدخل. كما تنتشر نسبة الإعاقة بصورة أكبر في الثـريحة السكانية الأشد فقرا، وبين النساء والمسنين، وتزداد مخاطر التعرض للإعاقة بين أصحاب الدخل المنخفض، أو الإس العاطلين عن العمل. وفي محافظة واسط يعاني الأفر اد ذوو الإعاقة معدلات فقر أعلى بالمقارنـة مـع غير ذوي الإعاقة، و على الاغلب يتعرض ذوو الإعاقة والعـائلات التي في أفر ادها شخص معوق الى معدلات أعلى من

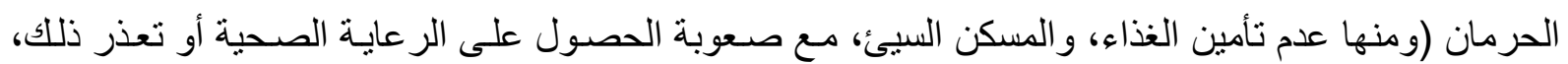
كذلك تزداد الكلفة التي يتحملها ذوو الإعاقة بسبب ما يحتاجون إليـه من دعم شخصـي أو رعايـة طبيـة أو أجهزة مساعدة) ، وفي الأسر منخفضة الدخل، يزداد احتمال مجابهة ذوي الإعاقة للنفقات الصحية الباهظة بنسبة .0\% 
من الأشخاص غير ذوي الإعاقة. ولمعرفة أثر دخل الأسرة على ظاهرة الاعاقة وتباينها المكاني تمت دراسـة المستوى المعيثـي لسكان محافظـة واسط تبعـا للـدخل الثـهري لأسـر تللك الوحدات الاداريـة، اذ اوضـح مؤشر

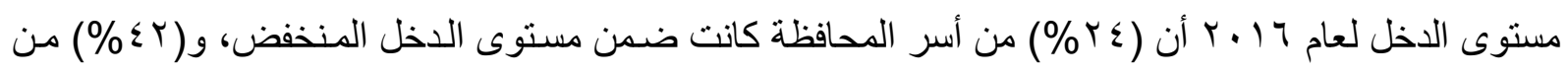
الأسر كانت ضمن مستوى الدخل المتوسط ، و(ع؟\%) من الأسر كانت ضمن مستوى فوق المتوسط ( الدخل المرتفع ).(IV) وباعتماد الدراسة الميدانية فإن أسر عينة الدراسة قسمت بحسب دخلها إلى ثثلاث فئات هي:الفئة الأولى: تشعل الأسر التي يقل دخلها عن . . .0 ألف دينار شهرياً. الفئة الثانية: يتر اوح دخل أسر ها بين . .0 ألف - مليون دينار شهرياً. الفئة الثالثة: يزيد الدخل الثهري لهذه الفئة عن مليون دينار شهرياً. .

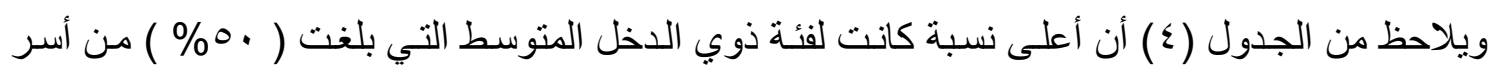

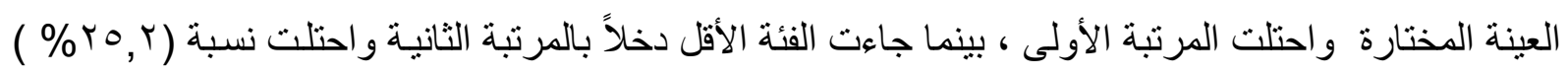

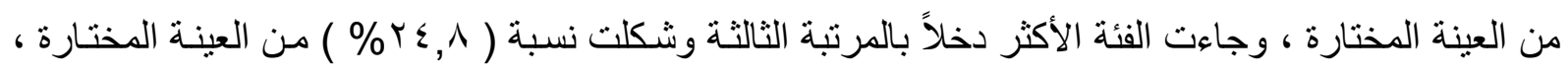
آخذين بنظر الاعتبـار أن التباين المكاني للفئات الثناث لمستويات الدخل الثـهري قد تباينت بين وحدة إداريـة و أخرى، بحسب ما يوضحه الجدول المذكور.

اذ نجد ان مركز قضـاء الكوت احتل النسبة الاعلى لفئة الدخل المتوسط ( . .0 الف ـ مليون) وبلغت

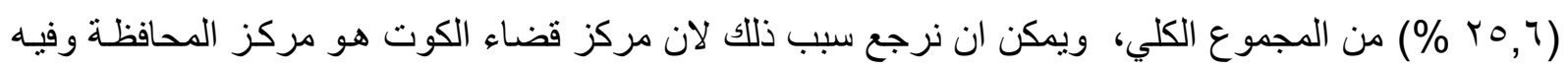

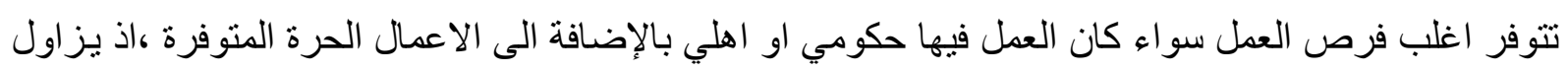

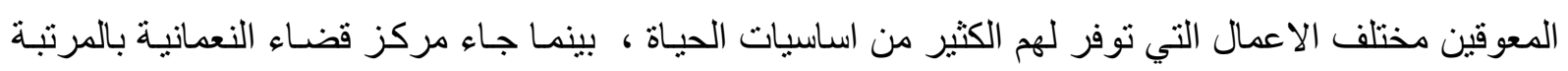

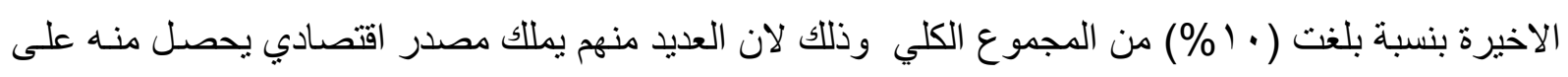
نسبة من المال تساعده على سد احتياجاته اذ نجد نسبته قد ارتفعت في فئة الدخل المرتفع لتصل الى (ب, (1\%) من المجموع الكلي ، امـا بالنسبة لفئة الدخل المنخفض ( اقل من مـ . .0 الف ) فقد جـاء مركز قضـاء الحي

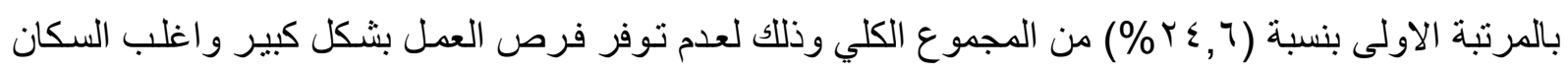
المعوقين يعملون بمهن حرة تدر عليهم نسبة قليلة من الاموال والتي لا توفر جزء من حاجاتهم الاساسية ، و واحتل مركز قضاء النعمانية المرتبة الاخيرة للأسباب التي ذكرت مسبقا، ونجد ان فئة الدخل المرتفع (اكثر من مليون )

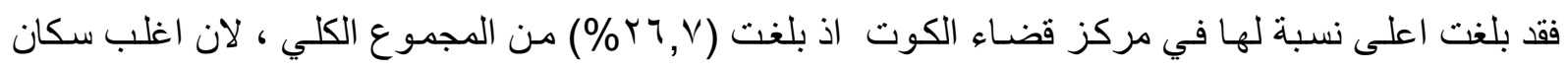

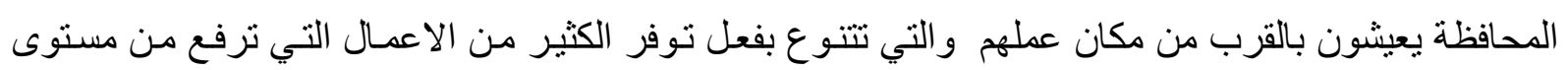
الدخل ، وتوزعت النسب الاخرى بين مر اكز الاقضية الاخرى ومنها مركز قضـاء الصويرة و الحي و النعمانية

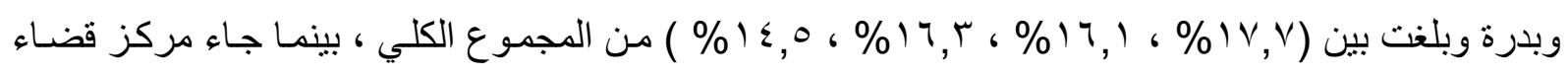

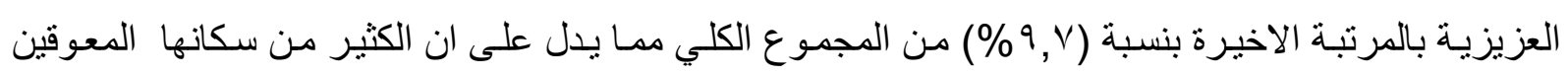

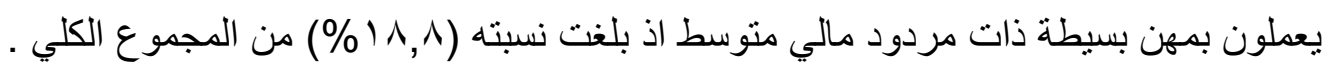




\begin{tabular}{|c|c|c|c|c|c|c|}
\hline \multicolumn{7}{|c|}{ جدول (؛ ) الدخل الثهري للمعوقين في محافظة واسط } \\
\hline$\%$ & أكثر من مليون & $\%$ & ل. دينار متوسط - مليون & $\%$ & أقلّ من مينار منخفض . ألف & الوحدة الإدارية \\
\hline$r q, V$ & $r r$ & Yo,r & $7 \varepsilon$ & $1 V, 0$ & YY & مركز قضاء الكوت \\
\hline $10, r$ & 19 & 1. & ro & $7, r$ & $\Lambda$ & مركز قضاءالنعماتية \\
\hline 17,1 & $r$. & $10, r$ & $r \Lambda$ & $r \leqslant, 7$ & 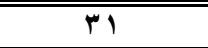 & مركز قضاء الحي \\
\hline $1 \leqslant, 0$ & 11 & $1 \leq$ & ro & 10,9 & $r \cdot$ & مركز قضاء بلرة \\
\hline$I V, V$ & YY & 17,8 & $\$ 1$ & $r r, \Lambda$ & $r$. & مركز قضاءالصويرة \\
\hline $9, \mathrm{~V}$ & Ir & $1 \wedge, \wedge$ & $\varepsilon V$ & 11,9 & 10 & مركز قضاءالعزيزية \\
\hline$r \varepsilon, \Lambda$ & $\overline{T Y \varepsilon}$ & $\% 0$. & YO. & $\%$ \%ro,r & $1 \% 4$ & المجموع \\
\hline
\end{tabular}

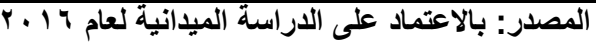

ان علاقة الارتباط بين نسبة الدخل الثهري المنخفض وعدد المعوقين قد بلغت ( ـ 1 ) (*) وهي علاقة سـالبة عكسية قويـة ، أي كلمـا انخفض مستوى الدخل الثـهري للأسرة كان هناك زيـادة في عدد الاشـخاص ، المعوقين، وهو نتيجة منطقيه ان هذه الأسر يصعب عليها توفير الأموال الكافية لعلاج المرضسى في العائلة ، وبالنتيجة تتردى الحالة الصحية مما يستحيل تماثل هؤلاء الأشخاص إلى الثفاء بسرعة ، وقد تؤدي إلى حصول نسبة معينة من الاعاقة لهم ، وخاصـة الاشخاص الذين يتعرضون للحوادث المروريـة او الاصسابة بطلق نـاري اثثـاء الحـرب وقد تكون اصـابتهم بليغــة يفقدون على اثرهـا اعضــاء مـن جسـهم ، وبالتـالي تزداد الصـعوبات و المشاكل لديهح و لا يستطيعون نوفير الحاجات الخاصة بهح و بعائلتهم من دو اء و غذاء ومسكن و غير ها .

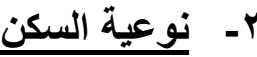

ان الحق في سكن ملائم للمعوقين يعد عنصراً هاماً يهدف بالأسـاس الى تمكين هذه الفئَة من العيش في مأوى مناسب يتو افق مع كر امتهم البشرية ، ولذا نجد ان المأوى الملائم يعني اكثر من وجود سقف يضل الافر اد ، فهو يعني ايضاً سهولة الوصول اليه والتحرك فيه ، اضافة الى توفر الخصوصية والأمن الكافي فيها ، بمـا في

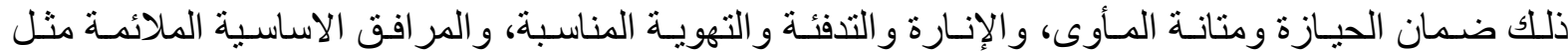
إمدادات المياه و المر افق الصحية ، ومكب النفايـات والبيئة النظيفة ،بالإضـافة الى الخدمات الصحية ، ويواجه المعوقون في محافظة واسط مشكلة جديـة على صعيد ممارسـة الحق في السكن ، تتمثنل في صعوبة التحرك داخل مناز لهم الخاصة ، و عدم مو ائمتها بشكل يتناسب مع احتياجاتهم كل حسب اعاقته ، كذللك صعوبة التنقل خارج المنزل ، فضلا عن وجود العتبات العالية والمرتفعة على مداخل البنايـات العامـة والتجارية و عدم توفر المصاعد الكهربائية فيها وخاصة البنايات القديمة ، مما يتطلب منهم طلب المساعدة من الاخرين لتمكينهم من دخول البنايات والخروج منها .(^') ورغم تطور الحركة العمر انية إلا ان القليل من البنايات تم فيها مر اعاة حاجـة المعوقين لاستخدامها ، و اغلب المبـاني الخاصـة و الحكوميـة لا تتمتع بالمو اصـفات الضـرورية لتمكين المعوقين من ارتيادها بسهولة ويسر ، فبعض المباني العامة حتى وان تمكن المعوق من الوصـول الى أي طابق فيها فانه يو اجه مشكلة تتعلق باستخدامه للمر افق الصحية فيها نتيجة لضيق مساحتها و عدم ملائمتها لاستخدامه . وان الاضطر ار للسكن في ظل ظروف صسعبة ووضـع غير مريح نتيجة للفقر والوضـع الاقتصـادي الصسب ، يترك اثـار أسيئة على الوضـع النفسي للمعوق ويزيد من شـوره بالضـف اتجـاه الاخرين ـ أن الازدحام في المنازل وعدم كفاية الخدمات العامة من أهم الأسباب المؤدية لانتشار الأوبئة (9').فمكوث أعداد كبيرة من أفر اد 


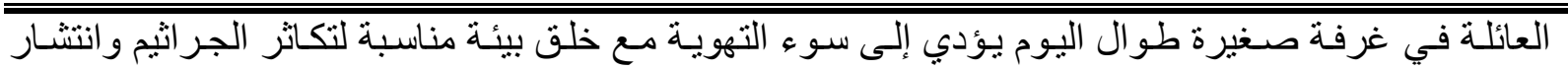
الأمر اض و إن تزامن سوء التهوية مع الرطوبة يزيد من احتمال حدوث عدوى لكثير من الأمر اض الفيروسية و لاسيمّا التنفسية (r) التي يكون الأطفال الرضع أكثر عرضة لهاء لضعن جهاز هم المناعي الحديث النشأة. يبين الجدول (0) نوع المسكن الذي يعيش فيه الثخص المعـاق ، اذ تبين ان نسبة المسـاكن الاقل

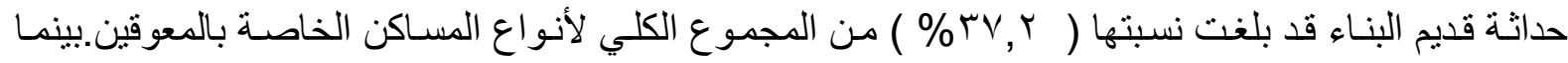

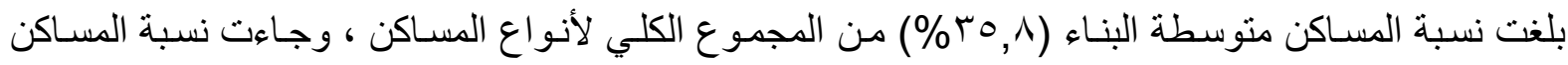
الحديثة البناء بالمرتبة الاخيرة وبلغت ( FV \% من المجموع الكلي لمساكن المعاقين. جدول (0) نوع المسكن الذي يعيش فيه المعوقين في محافظة واسط

\begin{tabular}{|c|c|c|c|c|c|c|}
\hline$\%$ & حليث & $\%$ & متوسط & $\%$ & قديم & الوحدة الإدارية \\
\hline $19, r$ & $r 7$ & $17, r$ & rq & $11, r$ & YI & مركز قضاء الكوت \\
\hline 11,0 & ro & $17, r$ & rq & $I V, r$ & rr & مركز قضاءالنعمانية \\
\hline$I V, \Lambda$ & $r \varepsilon$ & $1 v, 9$ & rr & 17,1 & $r$. & مركز قضاء الحي \\
\hline $1 \%, r$ & 11 & $11, v$ & YI & $r \cdot, \xi$ & $r \wedge$ & مركز قضاء بدرة \\
\hline 9,7 & ir & $1 \mathrm{~V}, 9$ & rr & 17,1 & $r$. & مركز قضاءالصويرة \\
\hline$r 1,0$ & rq & $r \cdot, 1$ & 14 & $1 \wedge, \wedge$ & ro & مركز قضاءالعزيزية \\
\hline rV & $1 \% 0$ & $r_{0, \Lambda}$ & 189 & $\overline{P r, r}$ & $1 \wedge 7$ & المجموع \\
\hline
\end{tabular}

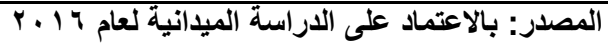

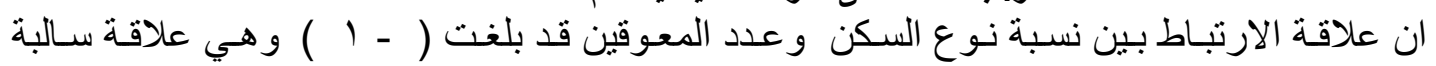
عكسية قوية ، أي كلما انخفضت نسبة نوعية السكن كلما ازداد اعداد المعاقين في الاسرة. r- المستوى التعليمى توجد فجوات في إكمال التعليم لدى جميع المجموعات العمريـة وفي كافة البيئات، ولكن العينة تكون أكثر بروزًا في الدول الأكثر فقرًا. وحتى في الدول التي يذهب فيها معظم الأطفال غير المعاقين إلى المدرسـة، لا يذهب العديد من الأطفال ذوي الإعاقات إلى المدرسة. على سبيل المثال في بوليفيا تذهب نسبة ه9 \% نقرييًا من الأطفال غير المعاقين إلى المدرسة، ولكن أقل من • ؛\% من الأطفال المعاقين يذهبون للمدرسـة. وفي إندونيسيا، يذهب إلى المدرسة أكثر من •^^\% من الأطفال غير المعاقين، ولكن أقل من هب\% من الأطفال ذوي الإعاقات يذهبون إلى المدرسة. وتثير الدراسات إلى تعدد أشكال وأساليب رعاية المعاقين ، ومن بين هذه الأسـاليب التي حظيت بانتشـار واسـع في الكثير من دول العـالم “أسلوب الدمج”. ومفهوم الدمج في جوهره مفهوم اجتمـاعي أخلاقي ، نابع من حركة حقوق الإنسان في مقابل سياسة التصنيف والعزل لأي فرد بسبب إعاقته، بغض النظر

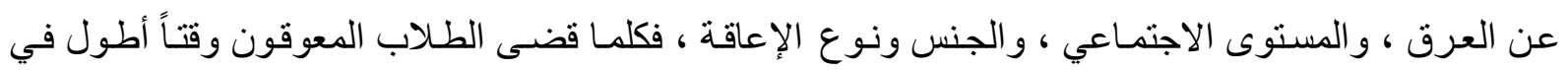
فصول المدرسة العادية في الصغر ، كلما زاد تحصيلهم تربوياً ومهنياً مع تقدهم في العمر ـ ولقد أوضحت نتائج

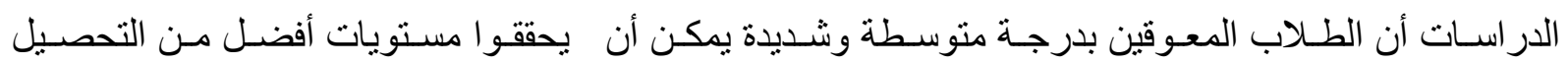
و المخرجات التربوية في الوضع التربوي العام.وعلى هذا الأساس عقد مؤتمر سلامنكا بإسبانيا في شـر حزيران

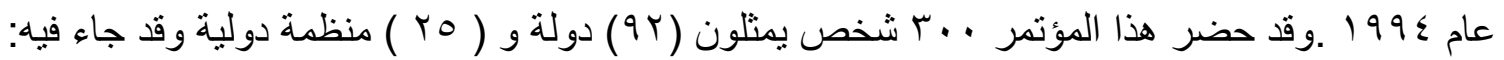
ـأن لكل معاق حقا أساسيا في التعليم ويجب أن يعطى الحق في بلوغ مستوى مقبول في التعليم والمحافظة عليه ـ أن لكل معاق خصائصه الفريدة واهتماماته وقدر اته واحتياجاته الخاصة في التعلي. 


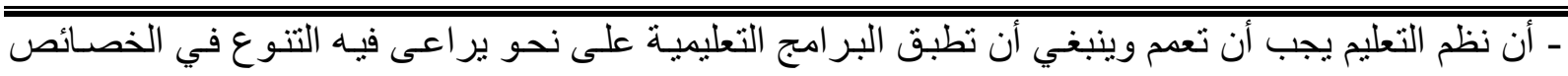
و الاحتياجات.

تمثل قضية تعليم المعاقين وتأهيلهم تحديًا حضاريًا للأمم و المجتمعات؛ لأنها قضية إنسانية بالدرجة الأولى، يمكن أن تعوق تقدم الأمم، باعتبار أن المعوقين يمثلون نسبة لا تقل عن • (\% من مجموع السكان على المستوى المحلي و الدولي، وتشكل هذه الأعداد الكبيرة منهم فاقدًا تعليميًا، يهدد الاقتصـاد الوطني و العالمي، وطبقًا لبعض الإحصـائيات المعلنة عبر الإنترنت فإن عدد المعاقين في العالم بيلغ · . . مليون شخص، أكثر من •ـ^\% منهم في الدول النامبة. ومهمـا اختلفت الإحصـاءات وتضـاربت الأرقام فالمشكلة الأكبر تتمثنل في ضـآلة عدد الذين يحصلون على الخدمات و الرعاية منهم في الدول النامية، إذ إن الذين بحصلون على الخدمات المطلوبة في هذا المجال بمثلون 9. 9 \% فقط من ذوي الاحتياجات الخاصة، حيث إنها تحتاج إلى مؤسسات سواء أكانت حكومية أم غير حكومية، بالإضـافة إلى

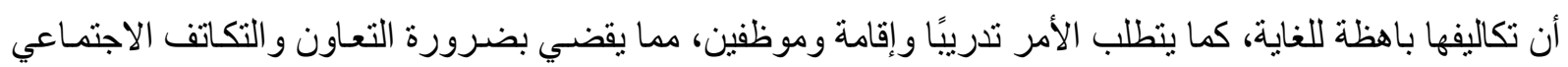
بين جميع الفئات في رعاية ذوب الاحتياجات الخاصة،، مع البحث عن جهات مانحة لمحاولة إدخال هذه الفئات و غالبيتهم

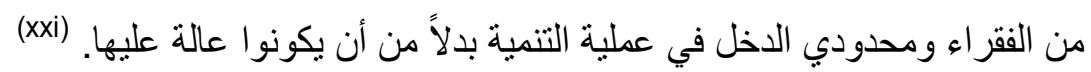
وفي محافظة واسط و إلى عهد قريب كان الاهنمام بالمعاقين مفقودًا على جميع الأصعدة و المستويات بصفة عامـة وفي المجـال التعليمسي بصفة خاصـة، فالمدارس والبيئات التعليميـة غير مناسبة، ولا يتو افر فيها الوسـائل و المصادر التعليمية المناسبة لهم، و لا الأجهزة والتجهيزات اللازمة، وبر امجهم التعليمية ومقرراتهم الدراسية غير مناسبة أيضًا، و المعلمون غير مدربين بدرجة كافية، وتكاد تخلو المدارس من أخصـائي تكنولوجيا التعليم المؤهل للعمل معهم.كان الحال سيبًا يزيدهم إحباطًا على إحباط ، ولكن في الآونـة الأخيرة بدا الاهتمام قويًَا بتلك الفئات ،

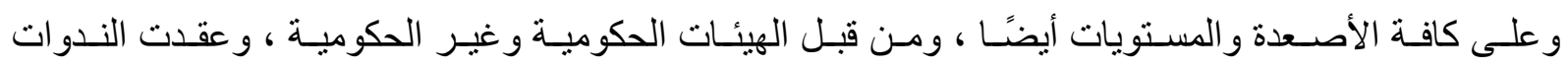
و المؤتمر ات سواء أكانت محلية أم دولية. فقد تم انتـاء معاهد خاصـة للتعليم فعلى الرغم من قلتها إلا انها تلبي

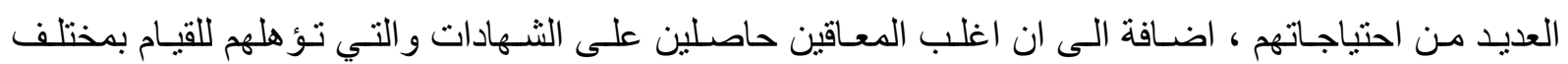
الوظائف وفعلا يوجد هناك موظفين لديهم نسبة اعاقة وهم يؤدون واجبهم على اكمل وجـه. ومن خـلال الجدول (7) يمكن ملاحظة المستويات التعليمية للمعاقين في محافظة واسط.

جدول (T) المستوى التعليمي للمعوقين في محافظة واسط

\begin{tabular}{|c|c|c|c|c|c|c|c|c|c|c|c|c|c|c|}
\hline$\%$ & |المجموع & $\%$ & اخرى & $\%$ & بكالوريوس & $\%$ & |عدادي & $\%$ & متوسط & $\%$ & |ابتدائي & $\%$ & امي & الإدارية \\
\hline$\% 1 \ldots$ & $1 \leqslant 0$ & $\overline{\lambda \Lambda, r}$ & 14 & $r \leqslant, 1$ & ro & 10,9 & $\overline{r r}$ & 17,7 & $\bar{r}$ & $\bar{r}$. & rq & $10, r$ & Pr & مركز قضاء \\
\hline$\% 1 \ldots$ & $\overline{187}$ & $0, r$ & $\bar{\varepsilon}$ & ro & 19 & $\overline{P r}, V$ & 11 & $11, \varepsilon$ & $1 \varepsilon$ & 19,1 & 10 & $\bar{v}, q$ & 7 & قضاء/النعمانية \\
\hline$\%$ & $\overline{\Lambda 0}$ & 11,1 & $\overline{1 .}$ & Y. & IV & $\overline{P r, O}$ & $r$. & $10, r$ & $1 T$ & $9, \varepsilon$ & $\bar{\Lambda}$ & $r$. & IV & مركز قضاء \\
\hline$\% 1 \ldots$ & $\Lambda \varepsilon$ & $r, 7$ & $r$ & $1 V, 9$ & 10 & 9,0 & $\Lambda$ & ro & $r_{1}$ & $r \leqslant, 0$ & rq & 9,0 & $\Lambda$ & مركز قضاء \\
\hline$\% 1 \ldots$ & 09 & $1 Y, 0$ & $\bar{v}$ & $r, 0$ & $\bar{r}$ & ro & $1 \varepsilon$ & $1 \cdot, v$ & 7 & $r \cdot, \xi$ & IV & $1 V, 9$ & 1. & قضاء|لصوير \\
\hline$\% 1 \ldots$ & $0 \leq$ & $r, v$ & $\bar{r}$ & $1 \pi$ & $\bar{v}$ & $r \cdot, \xi$ & 11 & 17,1 & 9 & 11,0 & 1. & $r v, V$ & 10 & قضاءالعزيزية \\
\hline
\end{tabular}




\begin{tabular}{|c|c|c|c|c|c|c|c|c|c|c|c|c|c|c|}
\hline$\%$ & $0 \ldots$ & $\% \vee,{ }^{4}$ & $r \wedge$ & $\% 19$ & 90 & $\% \backslash \wedge, \wedge$ & $9 \leq$ & $\% \backslash \vee, \xi$ & $\overline{\lambda \nu}$ & $\begin{array}{c}41,7 \\
\%\end{array}$ & 1.1 & $\% 10,4$ & $\checkmark \wedge$ & المجموع \\
\hline
\end{tabular}

\section{ع - المؤسسات الصحية}

لابد من الاكتشــاف المبكر للإعاقـة والتدخل العلاجي المبكر وتقديم مجموعـة من حملات التطعيم ضد الأمر اض المؤدية إلي الإعاقة و التأمين الصحي ـوفي الوقت الراهن تقوم وزارة الصحة بإدارة وتمويل جميع المستشفيات الحكوميـة ومر اكز الرعايـة الصحية الأولية بطريقة مركزيـة، ويتم تخصيص الميز انيات حسب الفقرات (الرواتب، المو اد، الخدمات، رأس المـال). و لا توجد هنالك معايير لتقييم الناتج أو الأداء، كما لا توجد حو افز للتحسن الذي قد يتحقق في الكفاءة والنوعية. فضلا عن ذلك فإن المسؤولية الإداريـة ضعيفة جدا لأنه لا توجد هنالك أسس لتقييم الأداء، ويكاد أن يكون الاستمر ار في الوظيفة في القطاع الصـي مضمونا لجميع العـاملين بغض النظر عن كفاءة ونوعيـة الأداء. (xxii) والثخص المعـاق يحتاج الى مختلف الخدمات الصحية و التي تقع على عاتق الحكومة بضرورة توفير ما يحتاجـه من ادويـة ومستلزمات طبية تسـاعده على الاستمرار في قضـاء حاجاتهـ ، اذ تعد المؤسسـات الصحية من اهم الخدمات المجتمعيـة التي تسهم بشكل كبير في تقديم الخـمات العلاجيـه للسكان المعـاقين عبر مؤسسـات القطـاع الصـحي. ومـن الجدول (V) يتضـح ان المؤسسـات الصحية في محافظة واسط تتمثل بالمستشفيات و المر اكز الصحية فضلا عن عدد الاطباء وذوي المهن الصحية وتوزيع هذه المؤسسات يتميز بالتباين بين الوحدات الادارية و لا سيما المستشفيات و المر اكز الصحية التي تتركز معظمها في مركز قضاء الكوت ،و هي متخصصة بكافة انواع الامر اض وكافة العلاجات ، اما بالنسبة للمعاقين فقد خصص جناح في كل مستشفى ويقع خـارج بنايـة المستشفى ينت فيه تقديم بعض المستلزمات منها مركز الاطر اف الصناعية.

جدول (V) الخدمات الصحية في محافظة واسط

\begin{tabular}{|c|c|c|c|c|}
\hline عدد المرية اكز & الاطباء & المستثفيات & عدد السكان & الوحدات الادارية \\
\hline$r \cdot$ & rqs & $r$ & $\leqslant 19 \leqslant M 1$ & مركز قضاء الكوت \\
\hline $\mathrm{V}$ & $\varepsilon r$ & $r$ & 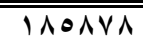 & مركزقضاء النعمانية \\
\hline 9 & ry & 1 & r.rVVq & مركز قضاء الحي \\
\hline$r$ & Ir & - & $r v .79$ & مركز قضاء بدرة \\
\hline Ir & 109 & 1 & $r . V V 10$ & مركزقضاءالصويرة \\
\hline 7 & $\varepsilon V$ & $\overline{1}$ & $1 \wedge V \cdot 71$ & مركزقضاءالعزيزية \\
\hline OV & 79. & $1 \wedge$ & $1 Y \varepsilon .94$. & المحافظة \\
\hline
\end{tabular}

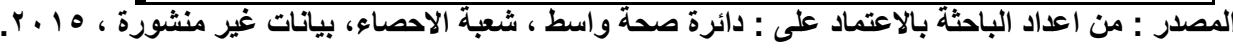

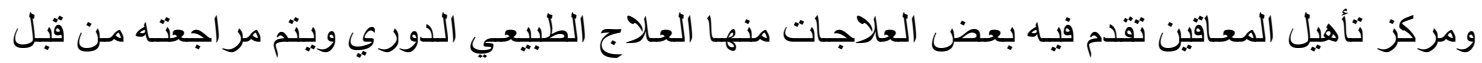
البعض وليس كل المعاقين لأنه لا توفر لهم كافـة الاحتياجـات مثل الكرسي المتحرك او المقعد الخـاص بقضـاء الحاجات و غير ها و الكثير منهم يلجأ الى شر اءها من الاسواق *، وبالتالي فأن العامل الصحي يعتبر من العوامل التي تؤثر على المعاقين من خلال نوفير ها لمختلف الحاجات و التي يصعب الحصول عليها من خارج المر اكز الخاصة بر عايتهم وان قلتها و عدم توفير ها لهذه الحاجات يشكل عائق امام الثخص المعاق. 
يقصد بييئة محل الاقامة توزيع السكان بين الحضر والريف ولهما جو انب عديدة مؤثرة على الاشخاص المعاقين من حيث توفر الخدمات المختلفة في الحضر وقلتها في الريف ، من حيث الخدمات التعليمية و الصحية والصناعية وطرق النقل و غير ها ، وكذلك تزيد او تقلل من ظـاهرة الاعاقة. ويتبين من الجدول (^) ان اغلب

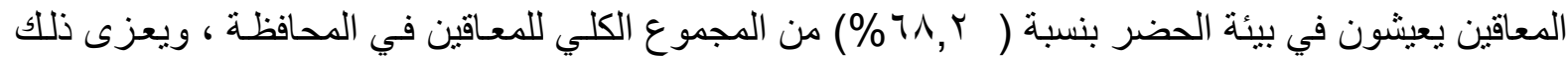
الى توفر مختلف الخدمات التي يحتاجونها والتي تسهل لهم مسيرة الحياة وخاصـة من ذوي الاحتياجـات الخاصـة و الذين يتطلب سكنهم ان يكون في الحضر ليكونوا قريبين من المؤسسات التي تتعلق بحياتهم اليومية كالمدارس الخاصة وبعض العلاجات الدائميـة والدوريـة ، وتزداد نسبة المعاقين ايضـا لكون تكثر فيـه الحوادث المروريـة والانفجار و هذه الاسباب سيتم سردها لاحقا في موضوع اسباب العوق ، امـا نسبة المعاقين الذين يعيثون في الريف فقد بلغت ( ^, ا؟\%\%) من المجموع الكلي للمعاقين في المحافظة ، و غالبا ما يكون هؤلاء من الكبار الذين اعتادوا على العيش في الريف لكونهم اصـابو ابـالعوق من فترة طويلـة خـلال الحرب العر اقيـة الاير انيـة عـام

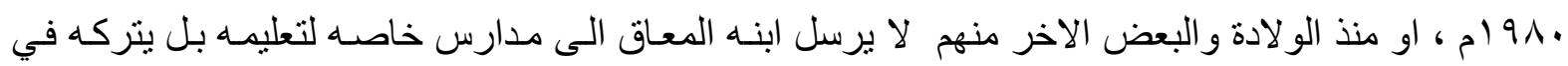
المنزل ليعتاد على العيش هنـاك ويتعلم الاعمـال الخاصـة بـالريف منهـا الرعي و الصيد الـخ ، اضـافة الـى قلـة الحوادث المسببة للإعاقة ـ ونجد من الجدول ايضـا ان اعلى نسبة للمعاقين في الحضر قد سجلت في مركز قضاء الحي اذ سجلت (•^^\%) من مجموع المعاقين في الحضر ، ويعزى ذلك لكبر مساحته وزيـادة عدد سكانه مما يجعلهم اكثر عرضة للحو ادث و الأمر اض و التي تزيد من ظاهرة الاعاقة ، بينما سجلت ادنى نسبة للمعاقين في الحضر في مركز قضاء بدرة (\%,09\%) من مجموع المعاقين في الحضر ، لقلة عدد السكان ، بينمـا نجد العكس ان اعلى نسبة للمعاقين في الريف قد سجلت في مركز قضساء بـدرة وبلغت (0, • ؛ \%) من مجموع المعاقين في الريف وذللك لان اغلب سكان القضاء يمارسون الرعي في الار اضي الخضر اء والتي تمتاز بوجود

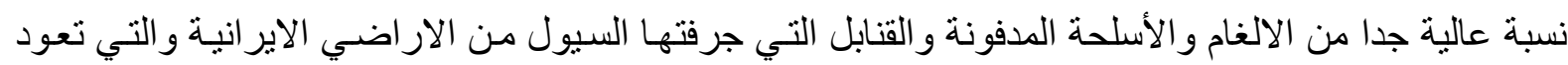
للحرب العر اقيـة الايرانيـة والتي سـاهمت وبشكل كبير في زيـادة اعداد المعاقين في المحافظـة عامـة ومركز

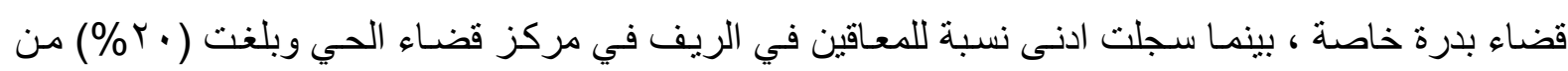
مجموع المعاقين في الريف و أغلبهم يعود سبب العوق للحرب و الو لادة.بينما تراوحت النسب الاخرى بين القيم.

جدول ( ^) بيئة محل الاقامة للسكان المعوقين في محافظة واسط

\begin{tabular}{|c|c|c|c|c|c|c|}
\hline$\%$ & المجموع & $\%$ & ريف & $\%$ & حضر & الوحدة الإدارية \\
\hline $1 \cdots$ & $1 \leqslant 0$ & $r 4,0$ & or & 74,0 & $q r$ & مركز قضاء الكوت \\
\hline $1 \cdots$ & V7 & rq & Yr & 81 & $0 \leq$ & مركز قضاعالنعمانية \\
\hline $1 \cdots$ & 10 & $r$. & IV & $\Lambda$. & 71 & مركز قضاء الحي \\
\hline $1 \cdots$ & $\Lambda \varepsilon$ & $\varepsilon \cdot, 0$ & $r \varepsilon$ & 09,0 & 0. & مركز قضاء بدرة \\
\hline $1 \cdots$ & 07 & 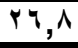 & 10 & $V Y, Y$ & $\varepsilon 1$ & مركز قضاءالصويرة \\
\hline $1 \cdots$ & $0 \leqslant$ & $r r, r$ & 11 & $77, V$ & $r q$ & مركز قضاءالعزيزية \\
\hline $1 \cdots$ & $0 \ldots$ & $\overrightarrow{\mu 1, \Lambda}$ & 109 & $7 \wedge, r$ & $r \leqslant 1$ & المجموع \\
\hline
\end{tabular}

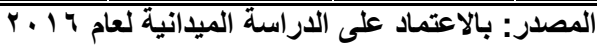


خاهسا: انواع الاعاقة

1. الاعاقة الحركية: هي الاعاقة الناتجة عن خلل وظيفي في الأعصـاب أو العضـلات أو العظام والمفاصل

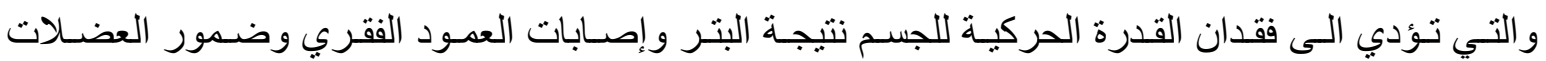
و وارتخائها ـ و المعوق حركيا هو الثخص الذي لديهه عائق جسدي يمنعهـه من القيام بوظائفه الحركية بشكل طبيعي نتيجة مرض أو إصابة أدت إلى ضمور في العضـلات أو فقدان القدرة الحركية أو الحسية أو كلتيهمـا معاً في الأطر اف السفلى والعليا أحياناً أو إلى اختلال في التوازن الحركي أو بتر في الأطر اف، ويحتاج هذا الثخص إلى بر امج طبيـة ونفسية واجتماعية وتربويـة ومهنية لمسـاعدته في تحقيق أهدافه الحياتيـة و العيش بأكبر قدر من الاستقلالية.ومن حالاتها شلل الاطفال والنزف في العظام وتنخر هـا و الثنلل الدماغي و المقعدون وتثنق العمود الفقري ، امـا اسباب حصول الاعاقة الحركية فهي الاسباب الور اثية الولاديـة والأسباب البيئية أو الاجتماعية والتي تتعرض لها الام الحامل اثناء الحمل من امر اض او حوادث،وتختلف النسبة لهذه الاعاقـة من مجتمع إلى آخر وذللك لأمر يتعلق بثقافة هذا المجتمع أو ذاك حول الوعي الصحي و الثقافي، إضـافة إلى الى العو امل الور اثية، و المعايير المستخدمة في تقدير نوع الإعاقة الحركية، كذلك إلى الاختلاف في تحديد معايير الإعاقة الجسدية وعدم وجود اتفاق بين العلمـاء حول تعريف الإعاقة الحركية إضـافة إلى عوامل الظروف المستجدة مثل: الكوارث الطبيعية ( الزلازل ـ الفيضاناتـ إلخ ) و الحروب ، مثل حرب أمريكا على المجتمع العر اقي مدـا أدى إلى زيـادة انتشـار حسالات الإعاقـة الحركيـة. وحسب الإحصـاءات الأمريكيـة فـإن نسبة المصابين في العر اق بالإعاقات الحركية بلغت (ع\%) رغم التقدم الطبي والعناية الصحية، وتشير التقارير أن هذه النسبة في ازدياد. ويمكن تقدير نسبة هذه الإعاقـة في المجتمعات الأخرى من خـلال التقارير الإحصـائية

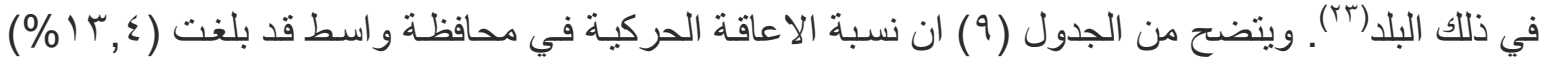

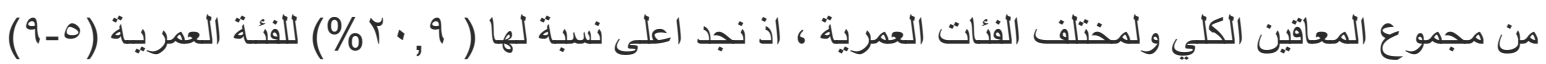
سنة ويعود سبب ذلك الى العوامل الور اثيـة وتظهر قبل الولادة او اثناء الولادة او بسبب الاصـابة ببعض

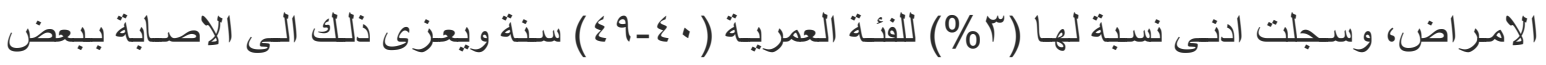
الامر اض والتي تسبب لهم العوق او الاصدابة من جراء العمل او الحروب والحو ادث وغير ها .

\begin{tabular}{|c|c|c|c|c|c|c|c|c|c|c|c|c|}
\hline$\%$ & ذذهية & $\%$ & حركية & $\%$ & عقلية & $\%$ & نطقية & $\%$ & سمعية & $\%$ & بصريـة & الفئة العمرية \\
\hline$r, V$ & $\varepsilon$ & $1 \leqslant, 9$ & 1. & 17,1 & $r$ & $r \cdot, \varepsilon$ & $\overline{r \varepsilon}$ & $r \theta, V$ & 19 & 9,5 & $\bar{\Lambda}$ & $\varepsilon-\infty$ \\
\hline$\varepsilon, V$ & $\bar{v}$ & $r \cdot, q$ & 18 & 11,1 & 0 & $r Y, \Lambda$ & 11 & rV & $r$. & $1 \leqslant, r$ & Tr & 9.0 \\
\hline 17,8 & ro & 11,9 & $\Lambda$ & $r v, \wedge$ & IV & $\Lambda, q$ & $\mathrm{v}$ & $7, v$ & 0 & $r, 0$ & $r$ & $19-1$. \\
\hline 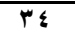 & 01 & $1 T, \varepsilon$ & 9 & $r \wedge, q$ & 14 & $10, Y$ & Ir & $17, r$ & Ir & $\Lambda, r$ & $\mathrm{~V}$ & $r q-r$. \\
\hline$I Y, V$ & 19 & $1 T, 2$ & 9 & $7, V$ & $r$ & $1 \cdot, 1$ & $\bar{\Lambda}$ & $7, \wedge$ & 0 & $1 \cdot, 0$ & 9 & rq-r. \\
\hline $1 \pi, r$ & $r$. & $r, \cdot$ & $r$ & $r, Y$ & 1 & $v, 7$ & 7 & 9,0 & V & 14,9 & 11 & $\varepsilon q-\varepsilon$. \\
\hline Tr & 11 & $1 v, 9$ & Tr & $\varepsilon, \varepsilon$ & $r$ & $r, \Lambda$ & $r$ & $0, \varepsilon$ & $\varepsilon$ & $r r, 0$ & $r \cdot$ & 09.0. \\
\hline$\xi$ & 7 & $\varepsilon, 7$ & $r$ & $r, r$ & 1 & $1, r$ & 1 & $r, V$ & r & 18,7 & 10 & • 7 سنة فأكثر \\
\hline$r$. & 10. & $1 T, \varepsilon$ & $7 V$ & 9 & $\leqslant 0$ & 10,1 & $\sqrt{89}$ & $1 \leqslant, \wedge$ & $V \varepsilon$ & IV & 10 & المجموع \\
\hline
\end{tabular}


r. الاعاقة الحسية: وهي الاعاقة الناتجة عن إصابة الأعصاب الر أسية للأعضاء الحسية، كالعين أو الأذن أو اللسان وينتج عنها اعاقة حسية بصرية، ومن اسبابها العيوب الخلقية ، امر اض العيون ، سوء التغذيـة ـ أو

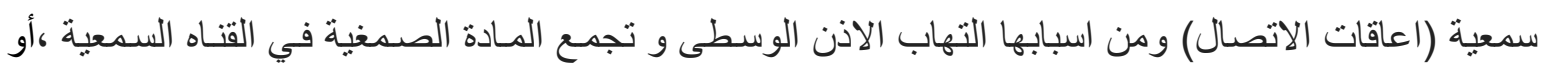

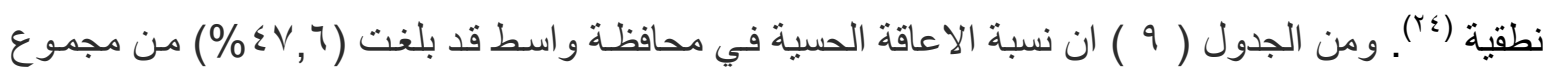

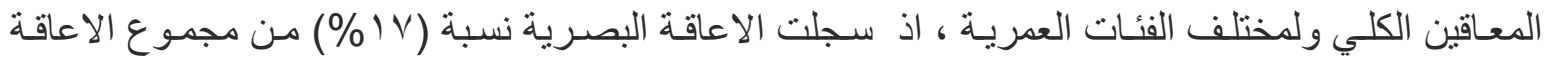

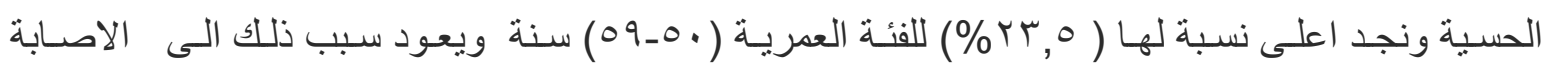

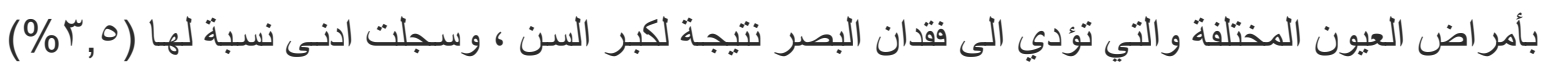
للفئة العمرية ( • ـ9 (1) سنة ويعزى ذللك الى الاصـابة ببعض امر اض العيون منذ الو لادة او نتيجة للعامل

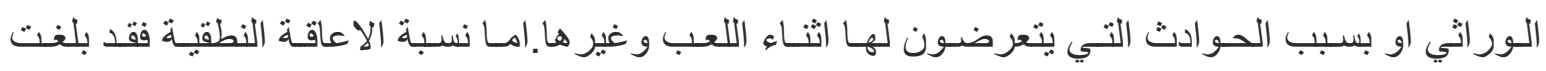

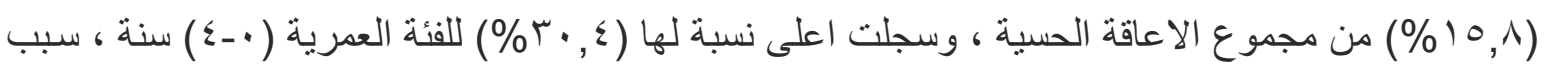
ذللك يعود للمرض منذ الو لادة ، بينما بلغت ادنى نسبة لها (r, (\%) للفئة العمريـة ( 7 سنة فأكثر ) يعود

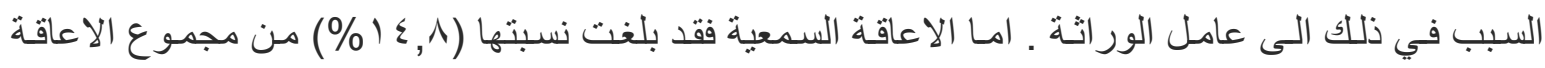

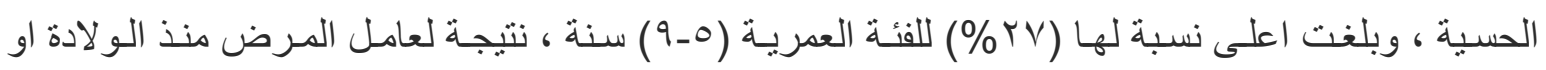

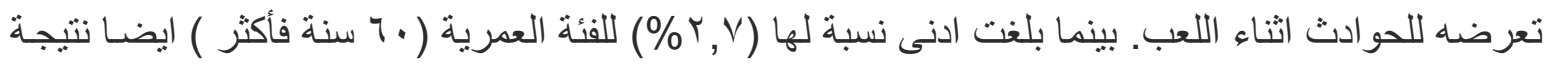
لعامـل المـرض او الحـوادث ، امـا بقيـة النسـب للإعاقـة الحسية بمختلف انو اعهـا فقد تراوحت بـين النسـب المذكورة .

r. الاعاقـة الذهنيـة : و هـي الاعاقـة الناتجـة عن خلل في الوظائف العليـا للـماغاغ، كالتركيز و العد و الذاكرة و الاتصـال مع الاخرين ، وينتج عنها اعاقات تعليميـة أو صسوبة تعلم، أو خلل في التصرفات والسلوك العام للشخص .وتعني ان كل نقص او ضعف او قصور في العمليات العقلية من شأنه ان يؤثر في عمليات الادر اك و النطق والتو اصل مما يؤدي الي ان يصبح الفرد غير قادر علي النمو العقلي او اكتشاف المهار ات و التواصل الاجتماعي ـ ان اسباب التخلف العقلي او الاعاقة الذهنية كثيرة ولكن هنالك اسباب رئيسية تنلخص في عوامل وراثيـة ـ اضـطر ابات التمثيـل الغذائي ـ الامـر اض ـ الحـوادث ويمكن ايجـاز الاسبـاب قبـل الـزواج (زواج الاقارب ) - الحمل -اثناء الوضع - السنوات الاولي من العمر (التطعيم ) - تأخر في النمو اللغوي ـ تأخر في النمو العقلي - تأخر في النمو اللفظي- تأخر في النمو الانفصـالي واضطر ابات في التفاعل مـع الاحداث ـ اضطر ابات في النمو الاجتماعي ـ اضطر ابات في نمو الثخصية والقدرة علي التكيف ــ وقد صنفت الاعاقة الذهنية الى ثلاثة اصناف وحسب وجهات النظر المختلفة للبحتثين ، منها الطبي والسلوكي والتربوي ولكل منهم نسبة معينة لتحديد درجة العوق ، اما على اساس المرض او على اساس السلوك اليومي او على اسـاس

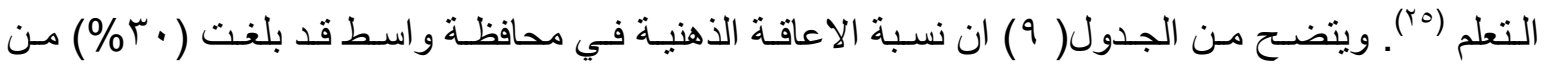

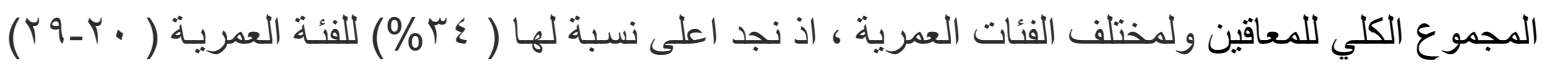
سنة ويعود سبب ذلك الى العو امل الور اثيـة وتظهر فبل الو لادة او اثتاء الولادة او بسبب الاصـابة ببعض الامر اض ، اضـافة الى التعرض لمختلف الحوادث ، على اعتبـار ان هذه الفئة هي الفئة العاملـة النشيطة

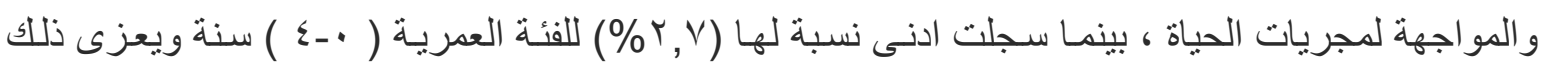


الى الاصـابة ببعض الامـر اض وقد تكون قبـل ولادتهم او اثنـاء الو لادة ، امـا بقيـة القيم للإعاقـة الذهنيـة فقد تر اوحت بين النسب المذكورة .

عـ الاعاقـة العقليـة : وهـي الاعاقـة الناتجـة عـن أمـر اض نفسية أو وراثيـة أو شــلل دمـاغي نتيجـة لـنقص الأوكسجين أو نتيجة لأمر اض جينيـة ـ و الإعاقة العقلية وجدت في كل العصور والأزمان ، فقد وجدت في الماضي وموجودة في الوقت الحاضر وستبقى موجودة في المستقبل بغض النظر عن الزمان والمكان و لا يكاد مجتمع يخلو منها ولكن نسبة الاعاقة العقلية قد تختلف من مجتمع الى مجتمع آخر لعدد من العوامل

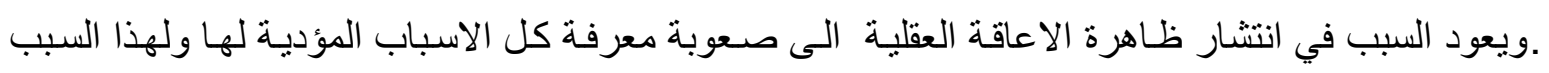
وبالر غم من كل بر امج الوقاية والرعاية الصحية لا زالت ظاهرة الإعاقة العقلية موجودة في كل المجتمعات وتعتبر فئة الاعاقة العقلية واحدة من فئات التربية الخاصـة الأكثر نسبة مقارنـة مـع فئات الاعاقات الاخرى وقد حظيت فئة الاعاقة العقلية بالكثير من الاهتمام الحكومي و غير الحكومي في العديد من الدول وظهرت الكثير من المؤسسات المحلية والدولية ومر اكز التربية الخاصة بالإعاقة العقلية . وتحدث الإعاقة العقلية في الغالبية العظمى نتيجة لعدة عوامل منتشابكة هي :

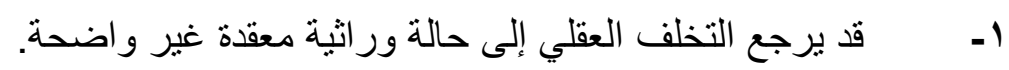

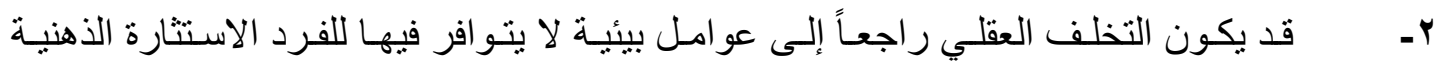
الملائمة، أو لا تتوفر العلاقات الاجتماعية المناسبة التي تسمح بالنمو الملائُ. قد تؤدي بعض الاضطر ابات الصحية أو الأمر اض إلى نوع من التلف البسيط في المـخ إلى الحد الذي لا لاعل يكون فيه التلف ملحوظاً عند البعض، مثل حالات سوء تغذية الأم الحامل، عدم العناية بالأم و الجنين بشكل ملائم

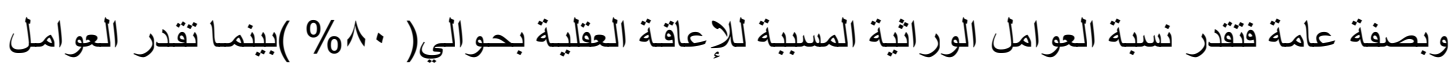

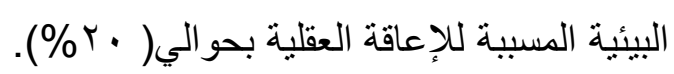
ويمكن تصنيف العو امل المسببة للإعاقة العقلية على أساس المرحلة الزمنية التي حدثت الإعاقة فيها إلى

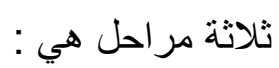
مرحلة ما قبل الو لادة ( أثناء فترة الحمل ) وتصنف ضمنها الاعاقة العقلية الاولية.

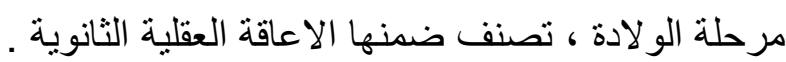

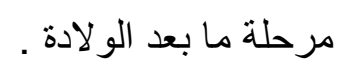

ويتم تثـخيص الثـخص المعـوق بالتشـخيص الطبـي مـن خـلال عرضـهـ على الاطبـاء ، او التشـخيص

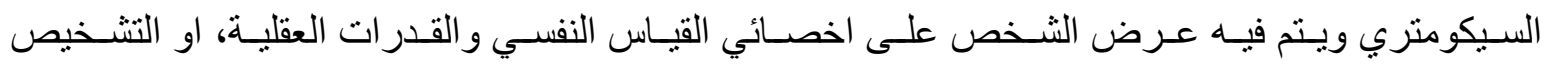
الاجتماعي للتعرف علي المعوقات الاجتماعية والتكيفية لدى المعوق عقلياً وذلك باستخدام مقاييس خاصـة مثنل مقيـاس السـوك التكيفي ومقيـاس النضـج الاجتمـاعي ـاو التشـخيص التربـوي ويتم بواسطة أخصـائي التربيـة الخاصة حيث يستخدم مقياس المهار ات اللغوية و التحصيلية : العدديـة ، القراء و الكتابة ، للتعرف على على القدرة على التعلم لدى المعوق عقليا ، او التشخيص الفـارقي والذي نفرق من خلاله بين الإعاقة العقلية والإعاقات الأخرى مثل التوحد، واضطر اب الكلام، وغير هـا. وتختلف نسبة الاعاقـة العقلية من مجتمع الى اخر ، كمـا لهـ 
تختلف تبعـاً لعدد من المتغيرات في ذلك المجتمع ، فهي تختلف بـاختلاف متغير درجـة الاعاقة العقليـة ، والجنس ( ذكور ، إناث ) والعمر .

ويتضح من الجدول ( 9) ان نسبة الاعاقة العقلية في محافظة واسط قد بلغت (9\%) من المجموع

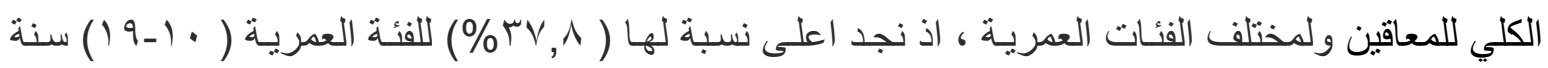
ويعود سبب ذللك الى العو امل الور اثية وتظهر قبل الولادة او اثناء الولادة او بسبب الاصـابة ببعض الامر اض

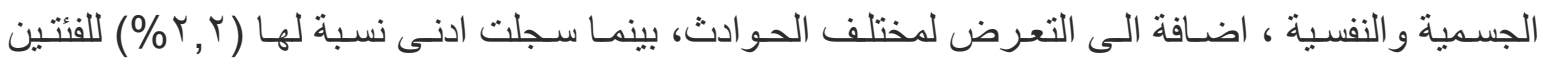
العمريتين ( • ـ ـ9 ) ) سنة و( • 7 سنة فأكثر) ويعزى ذللك الى ان اكثر المعاقين يكون المدى العمري لهم اقل

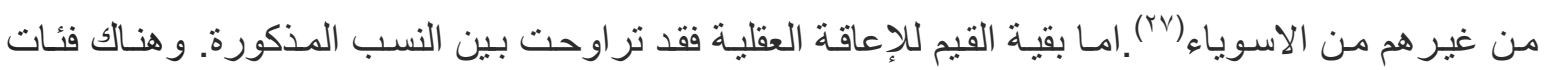

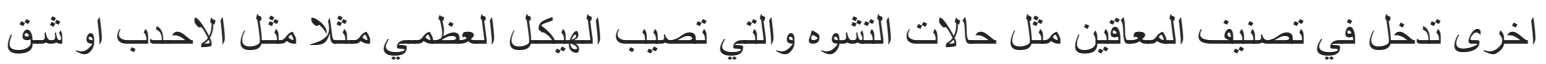
الثفاه او سقف الحلق ،كذلك هناك بعض الامر اض المزمنـة ومنها الحـالات الثديدة لأمر اض القلب و السل و السكر و الصرع ونزيف في المخ الخ · و هنالك المعاقين اجتماعيا وتتثل حالات الاجر ام و انحر اف الاحداث و المدمنين و السلوك العدو اني الحاد والانطو ائي الثديد وكذلك هناك فئة مزدوجي او متعددي الاعاقة .

\section{سادسا: اسباب الاعاقة}

أولاً: خَلقية.

ثانياً: عو امل أثناء الو لادة.

ثنالثاً: عو امل طارئة بعد الولادة.

رابعاً: عوامل ور ائية.

خامساً: عوامل اجتماعية وبيئية وأسرية .

أولاً: عوامل خَلقية

تؤُثر العو امل الخَلقية على تكوين الجنين وتؤدي إلى و لادة غير طبيعيـة ويكون امـا نقص في وزن أو

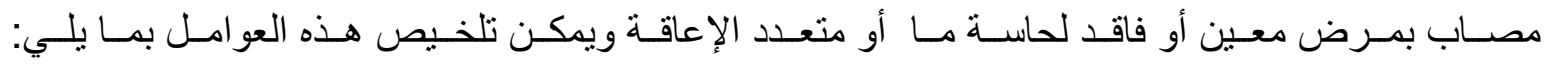
1 - نقص الغذاء للام الحامل فالنقص في بعض أنواع الفيتامين والبروتين يؤدي إلى بعض أنواع الخلل أو

الإعاقة عند الطفل.

r- إصابة الأم بالحصبة الألمانية: يجعل من السهل تعرض الطفل للتخلف العقلي أو إعاقة سمعية أو بصرية. ז- حالة الأم العاطفية والانفعالية: يتأثر الجنين بانفعالات الأم وتعرضها للضغوط، مما يؤدي إلى ولادة مبكرة أو عسر و لادة أو إجهاض و غير ها.. ثانياً: عوامل أثناء الولادة

ا ـ الو لادة العسرة: استخدام أدوات أو معدات مساعدة لسحب الطفل قد يؤدي إلى رضوض في الجمجمة. r- التفاف الحبل السري: يؤدي إلى نقص الأوكسجين مما يؤدي إلى تلف خلايا بالدماغ ينتج عنه تخلف عقلي أو شلل دماغي يتناسب مع حجم هذا التلف. 
rـ الو لادة غير الناضـجة: و لادة جنين بـوزن نـاقص أقل من r كن لهذا من الضـروري أن تتم الو لادة في المر اكز الصحية .

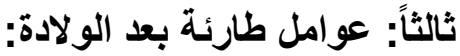

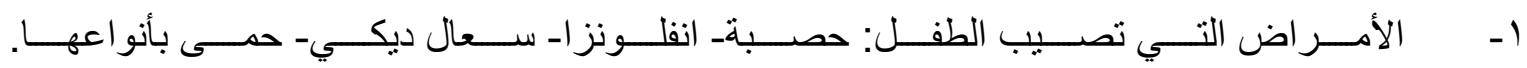

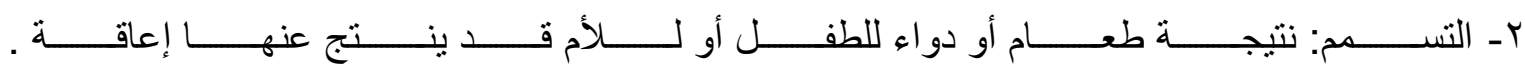
r- الإصابات الجسمية و الحوادث: سقوط- كسور - نزيفـ حو ادث مرور - حوادث منزليةـ كوارث طبيعيـــ

$$
\text { فيضانات- زلازل- حروب- جريمة. }
$$

عـ- نقص أو سوء التغذيـة: نقص بعض البروتينـات قد يؤدي إلى تخلف عقلي أو فقد البصر أو الكسـاح أو غير ها. هـ الجو المحيط الملوث: قطع الأشجار - نووي- مصانع - حروب- تلوث مياه وبحار. رابعاً: العوامل الاجتماعية ومستوى الرعاية الأسرية: وتتعلق بـ: مستوى الوعي- زواج الأقاربـ الزواج المبكر -الزواج المتأخر - عادات الصحة والو لادة و عدد الأطفال- تنظيم النسل وغير ها.

\section{خامساً: العوامل الوراثية:}

هي انتقال الأمر اض و إعاقات بالور اثثة عبر الأجيال (الأبوين والأجداد ) وليس بالضرورة ظهور ها مباثـرةً بل قد تنقل إلى أجيال لاحقة ، وبعض الدراسات تؤكد إلى أنها تنتقل حتى الجيل الخـامس وبعضـها يقول حتى بـى الجيل السابع ومن خلال الجدول ( · () اتضح ان سبب الاعاقة في المحافظة يعود للكثير من هذه الاسباب

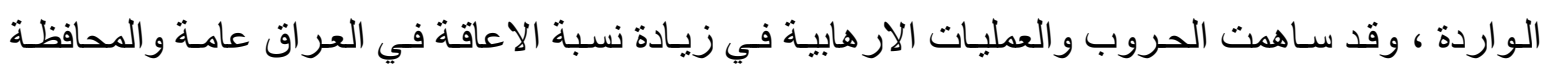
خاصـة ، اذ سـلت نسـب اسـباب الاعاقـة ولكل فئـة عمريـة ـ اذ بلغتت نسـبة سـبب الاعاقـة منـذ الـولادة

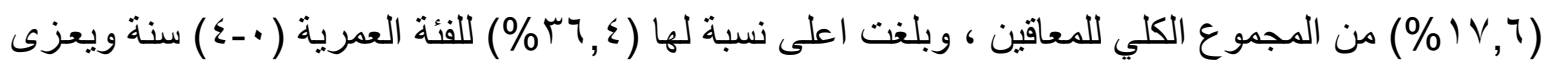
ذلك لكونهم صغار السن ولم يتعرضو الكل مجريات الحياة وبالتالي فهم مصـابون بـالعوق امـا قبل و لادتهم او

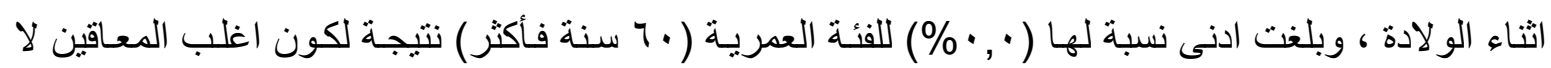
يصلون لهذا السن المتأخر من الحياة .اما نسبة سبب الاعاقة من جر اء العمل فقد بلغت نسبتها (ع,9\%) من

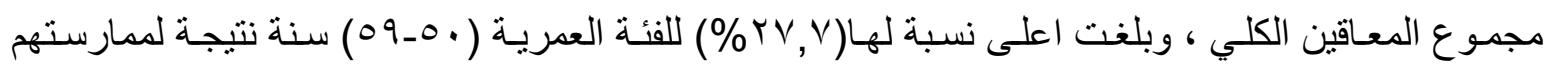
مختلف الاعمال كالحدادة والنجارة وتصليح المكائن والمعدات او تأسيس الكهرباء في الابر اج العاليـة وغير هـا من الاعمال التي قد يتعرضون من خلالها الى المخاطر ومن ثم الاصابة بالإعاقة ،بينما سجلت ادنى نسبة لها

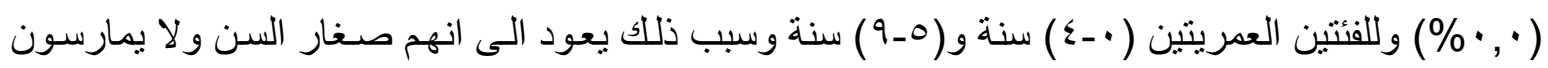

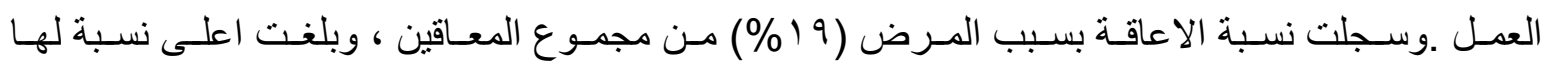

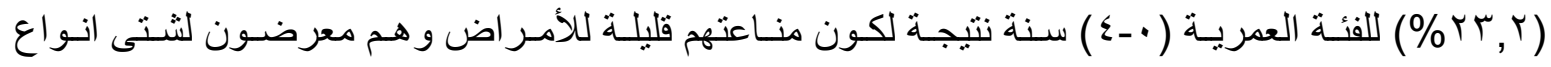

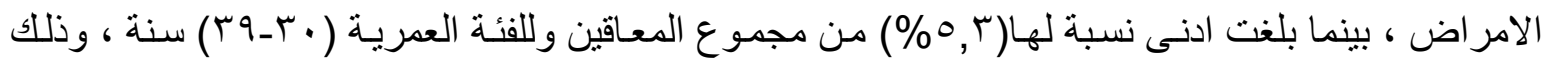
لأنهم قـادرين على مقاومـة الامـر اض مـن خـلال المر اجعـات للمؤسسـات الصـحية المختلفة و العنايـة بأنفسهـه وتوفير الحمايـة لها وبالتـالي فهم اكثر مقاومـة للأمر اض من الاطفـال. امـا نسبة المعاقين بسبب الحرب فقد 


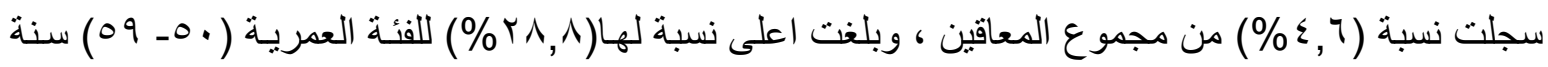
نتيجة لإصـابتهم في الحرب العر اقيـة الاير انيـة لعـام •و191 و التي استمرت ثمـان سنوات وقد سبيت الاعاقـة للكثير من الجنود انذاك و هم في مرحلة الثباب ، بينما بلغت ادنى نسبة لها ( , • \%) للفئتين العمريتين ( • ع ) سنة و(0_9) سنة وذلك لكونهم صغار السن ولم يشتركوا في الحرب .وسجلت الاعاقة بسبب الالغام الارضية

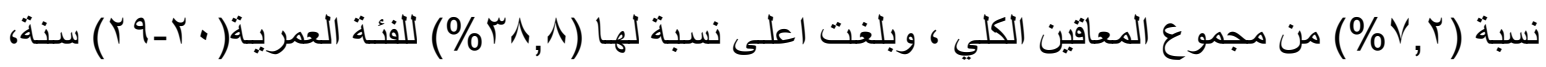
ويعزى ذلك لكون اغلب الثباب يذهبون الى المناطق الحدودية للمحافظة وبالأخص

\begin{tabular}{|c|c|c|c|c|c|c|c|c|c|c|c|c|c|c|}
\hline$\%$ & اخرى & $\%$ & مروري & $\%$ & ارنفجار & $\%$ & حرب & $\%$ & مرض & $\%$ & العمل & $\%$ & الولادة & العمرية \\
\hline $1 \cdot, r$ & $\varepsilon$ & $\bar{\Lambda} \wedge, r$ & 1. & $\overline{P, \cdot}$ & صفز & ${ }^{\prime \prime}$, & صفر & $\overline{r r, r}$ & $\overline{P r}$ & $\overline{c, \cdot}$ & صفر & $\overline{r q, \xi}$ & $\overline{T r}$ & $\varepsilon \ldots$ \\
\hline$r \cdot, \wedge$ & Ir & $r r, 1$ & $r V$ & 0,7 & $Y$ & $\because$, & صفر & 10,1 & 10 &,$^{\circ}$ & صفر & $r Y, V$ & $r$. & 9.0 \\
\hline$r \cdot, \theta$ & $\Lambda$ & $1 \cdot, V$ & $1 T$ & 19,8 & $\bar{v}$ & 11 & $\Lambda$ & $1,, 0$ & 1. & $r 1, r$ & 1. & $1 \cdot, r$ & 9 & 19.1. \\
\hline $1 Y, \Lambda$ & 0 & $r r, \bar{T}$ & $\leqslant 1$ & $r \wedge, \wedge$ & $1 \varepsilon$ & 9,7 & V & $r$. & 19 & $\varepsilon, r$ & $r$ & $7, \wedge$ & 7 & rq-r. \\
\hline 0,1 & r & 9,1 & $1 T$ & $\Lambda, r$ & $r$ & $r 1,9$ & 17 & $0, r$ & 0 & $\Lambda, 0$ & $\varepsilon$ & $1 Y, 0$ & 11 & $r q-r$. \\
\hline $1 r, \Lambda$ & 0 & $0, V$ & V & 17,1 & 7 & $r \cdot, 0$ & 10 & 9,0 & 9 & $\varepsilon, r$ & r & $r, 0$ & $r$ & $\varepsilon q_{-} \varepsilon$ \\
\hline $\mathrm{V}, \mathrm{V}$ & $r$ & $\varepsilon, Y$ & 0 & 0,7 & r & $r \wedge, \wedge$ & $r 1$ & $\Lambda, \varepsilon$ & $\Lambda$ & $r V, V$ & 14 & $v, q$ & V & $\Delta q_{-} \Delta$. \\
\hline$\cdot, \cdot$ & صفر & $0, V$ & $\bar{v}$ & 0,7 & $r$ & $\Lambda, r$ & 7 & $V, r$ & $\mathrm{~V}$ & $1 Y, \wedge$ & 7 & $\because$, & صفر & فأَثر سنة \\
\hline$v, \wedge$ & rq & $r \leqslant, \varepsilon$ & IYY & $v, r$ & rq & $1 \leqslant, 7$ & $V r$ & 19 & 90 & 9,8 & $\varepsilon V$ & 18,7 & $\Lambda \wedge$ & المجموع \\
\hline
\end{tabular}

لقضاء بدرة اما لجمع بقايا الاسلحة المتخلفة من جر اء الحرب الاير انيـة العر اقيـة لبيعها او قسم كبير منهم يذهب للنزهة الى تلك الاماكن لكونها تتمتع بالجو اللطيف والسماء الصافية وخاصة في منطقة زرباطيه و التي تقع بين الحدود العر اقية الاير انيـة والتي يتركز فيها النسبة الغالبـة من مخلفات الحرب و التهي جرفتها السيول واستقرت هنـاك ، وبالتـالي قد تعرض الكثير منهم للإصـابة والتعوق، بينمـا سجلت ادنى نسبة لها (

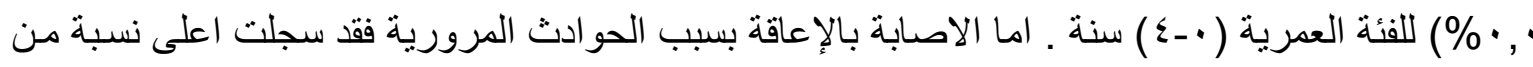

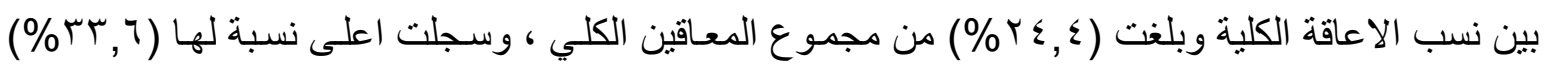

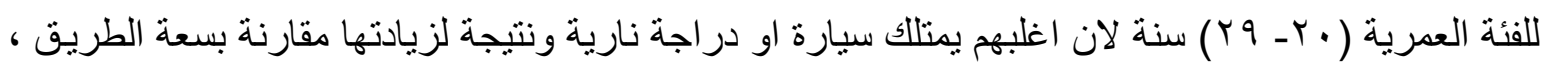
اضـافة الى وعورة الطرق واغلبها غير صـالحة للسفر صيفا وشتاء، والسـرعة العالية لأصحاب السيارات

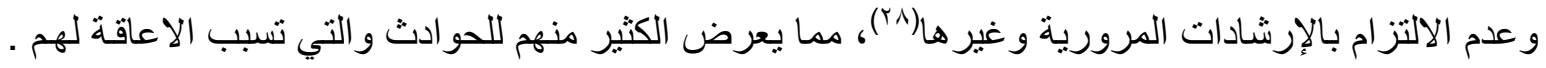

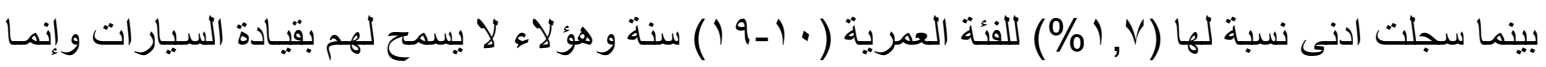
نتيجة لقيادتهم الدراجات النارية او اصـابتهم اثنـاء تعرض السيارة التي يستقلونها للحسادث ، او اثتـاء عبور هم

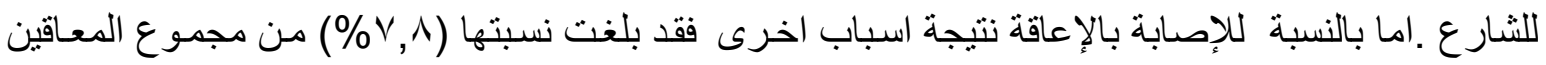
الكلي ، وسجلت اعلى نسبة لها (^, • r\%) للفئة العمرية (0_9) سنة ويعزى ذللك لكونهم في هذا العمر يكونوا اكثر حركة و أكثر مشاغبة واللعب في الادوات الجارحة والخطرة والصـود الى امـاكن عالية والخروج الى

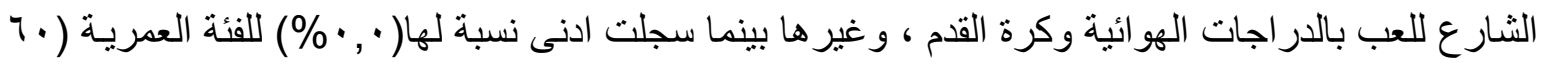


سنة فأكثر) وذلك لكونهم اقل حركة من غيرهم من الفئات العمريـة الاخرى وهم يكتفون فقط بـالجلوس

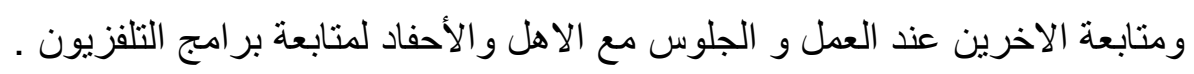

\section{سابعا: المشاكل التي يعاني منها المعاقين}

يو اجـه المعوقون الكثير من الضـغوطات و التوترات خـلال محاو لاتهم التكيف و التعـايش مـع بيئتهم

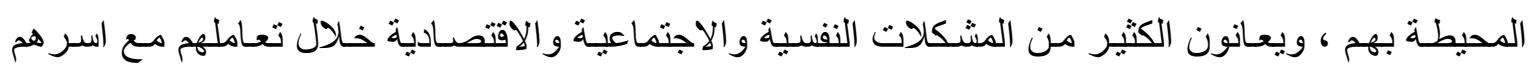
و أقاربهر ومؤسسات المجتمع المختلفة، ونتيجة لذلك فإنهم يفقدون الكثير من الامتياز ات فيعيشون حالة من ون الثعور بالضجر والاغتر اب ويحسون فيها بأنهم غير مقبولين من الأفر اد المعينين و المحيطين بهم ممـا يولدا لديهم الكثير من الانفعالات و الاضطر ابات النفسية بل إنها تجعلهم يعيشون حالة انفعالية تدفع بهم إلى تفسير خاطئ لكثير من المو اقف الحياتية التي ينظر إليها على أنها ضدهم رغم إنها ليست كذللك في حقيقتها.

أولا : مشكلات خاصة بالمعاق شخصيا 1 ـ مشكلات حياته الثخصية: نواجه المعاق في حياته اليوميـة الكثير من المشـاكل كعدم استطاعته الوفاء لوناء

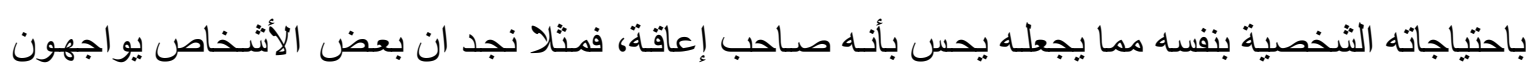

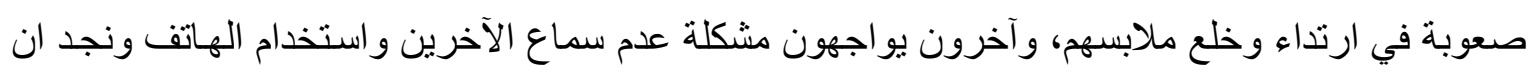
بعض الأفراد المعاقين تتقصهم المقدرة أو الطاقة اللازمة لكي يتحركوا بدون مسـاعدة، ونجد بعض المغ ونداقين

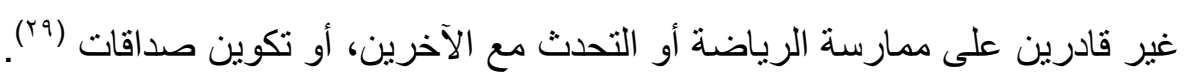
r- مشكلات المعاق النفسية : تنتاب الثخص المعـاق الكثير من المشاعر النفسية السلبية التي تؤثر عليه و على تو افقه واهم هذه المظاهر النفسية :

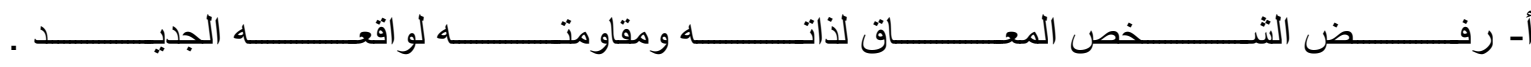

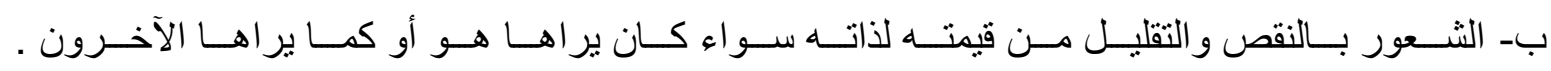

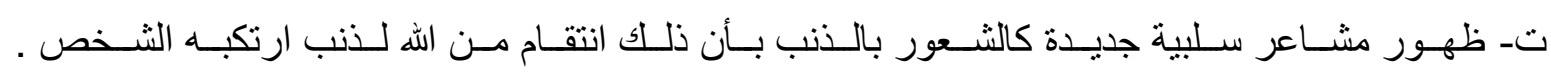
ثـ قد يستخدم المعاق ( حيل ) للهروب من الواقع الذي يثير قلقه وتونره كالتعويض والإسقاط والإنكار . r- مشكلات نفسية ناتجة عن تغير الظروف الاجتماعية والمهنية والاقتصادية وهي • وجوده تحت العلاج لفترات طويلة قد بؤثر على من بر عاهم، كما يؤثر على علاقاته بأفر اد الأسرة التي قد تصل إلى حد نبذ و إهماله. •التعطل نتيجة الإعاقة قد يؤدي إلى وجود فراغ لا يعرف المعوق كيف يستغله ممـا قد يجعله يلجـأ لأنواع

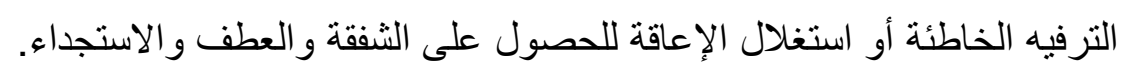
•إذا كان المعوق متزوج فقد يؤدي الوجود بعيدا عن الزوج أو الزوجة تحت العلاج، إلى غيرة المعوق، مما يؤدي إلى تفكك العلاقات الأسرية (·r). rـ مشكلات العمل: قد تؤدي الإعاقة إلى ترك المعاق للعمل أو تغيير لدوره إلى ما يتناسب مع وضعه الجديد

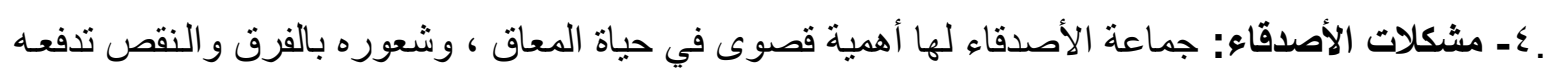
إلى الانعز ال والانطواء. - ماء. 
هـ المشكلات الترويحية: تؤثر الإعاقة على قدرة المعاق في الاستمتاع بوقت فر اغه سواء بالنشـاط الترويحي الذاتي أو الجماعي. وقد يؤدي عدم شـغل المعاق لوقت الفر اغ بطريقة سليمة ربمـا يقرب المعاق إلى سلوك انحر افي في بعض الأحيان

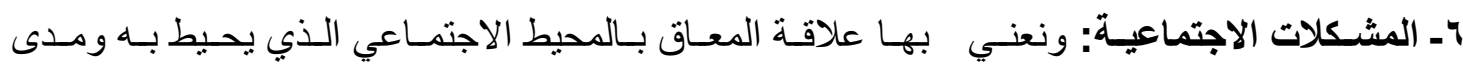
الاضطر اب الاجتماعي بينه وبين محيطه الاجتماعي الذي يتمثل في الأسرة والمجتمع. فبعض المجتمعات لا تقدر المعاق و لا تحترمه وتتجاهله، مما يؤدي إلى إحساس المعاق بالإحباط، هذا إلى جانب المضـايقات التي يتعرض لها وتذكيره بإعاقته، كما أن هنـاك بعض الفئات من النـاس التي ترفض مسـاعدته أو التعامل معـه.

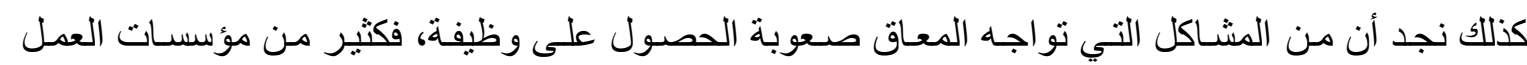
ترفض توظيف المعوقين على الرغم من ان المعوق قد تم تدريبـه وتعليمـه وتأهيله، و أحيانـا لا يعامل المعـاق من حيث الر اتب كما يعامل السوي مما يحول دون قدرته على توفير أساسيات الحياة، هذا بجانب ان الكثير من المؤسسات الاجتماعية ترفض توفير وسـائل نقل للمعاق من مسكنه إلى مكان عمله إلى غير ذلك من المشكلات على الصعيد الاجتماعي.

V- المشكلات التعليمية: وتبرز هذه المشكلات على الفرد المعوق نفسه وصعوبة التحاقه بالبر امج التعليمية،

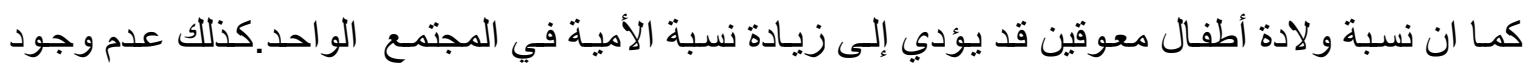
مدارس كافية للمعوقين و التي تسمح لـه بـالتعلم مع زمـاؤه المعاقين ،لان اغلبهم يشعر بـالنقص امـام الطلبـة الغير معاقين وبذلك يتخلص من الاستهز اء من قبل الاخرين و عدم شعوره بالنقص امـامهم. وتختلف الدول في وجهة نظر ها نحو مشكلة تعليم المعوقين ففي الدول الغربية المتقدمة حرصت على توفير مكان لكل عاجز مـع توفير وسـائل نقل خاصـة تؤمن وصـولهم بسـلام الى امـاكن تعليمهم تمشيا مـع المذهب الفردي وحقوق الانسان وصيغت انظمة لهم كما في الو لايات المتحدة الامريكية وانكلتر ا وألمانيا، اما في المجتمعات الاشتر اكية فان المذهب المجتمعي الذي تأخذ به فهو عدم تشجيع الفروق الفردية في نظم التعليم. إلا انهه في

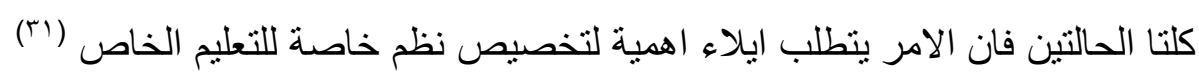
^ـ المشكلات الطبية: نجد المعاق يفتقد إلى الطب التأهيلي والعلاج الطبيعي وتوفير الفنيين والمختصين و الأجهزة الطبية الجيدة التي تخفف من شدة وحجم الإعاقة. و سواء كانت الاعاقة حسية او جسمية او عقلية هي عجز عضو او اعضاء عن القيام بوظيفة لأسباب ور اثية، او مكتسبة ميكروبية، او فايروسية، او كنتيجة

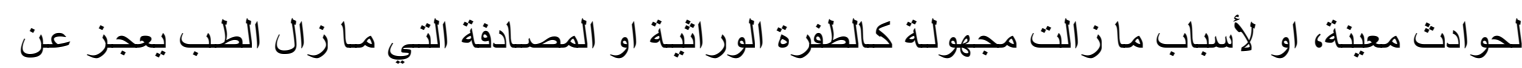
تفسير ها. ويمكن حصر المشكلات الطبية بما يلي:

1 ـ عدم معرفة الاسباب الحاسمة لبعض اشكال الاعاقة وخاصة الامر اض النفسية و العقلية. ז- طول فترة العلاج الطبي لبعض الامر اض وتكاليف هذا العـلاج كأمر اض التدرن والمرض العقلي و أمر اض السكر و القلب. r- عدم انتشار مر اكز كافية للعلاج المتميز للمعوقين بمستشفيات تر اعي ظروفهم ومشكلاتهم. 
ع- عدم توفر مر اكز كافية للعـلاج الطبيعي وخاصـة في المحافظـات مـع عدم توفر العدد الكافي من الفنبين والأجهزة الفنية لهذا العلاج.

9ـ نظرة المجتمع للمعاق : حيث نرى أن المعاق لا يعاني من مشكلات التكيف الثخصي بقدر مـا يعاني من مشكلات التكيف الاجتماعي في المجتمع الخارجي ، فنظر ات العطف والاشمئز از والازدر اء التي يلقاهـا المعاق من المارة تقتل فيه كل أمل يؤثر في تو افقه الذاتي في قبول إعاقته فالقبول الاجتماعي للإعاقة أصسب بكثير من القبول الذاتي لها فقد يستطيع المعاق أن يتو افق مع ذاتهـ ويتقبل إعاقته إلا أن رفض المجتمع لـه

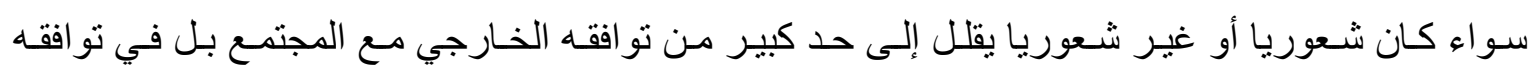

$$
\text { الثخصي مع ذاته . }
$$

ثانياً : المشكلات الأسرية الناجمة عن الإعاقة بشكل عام. اـ الإقامة في المستثفى العلاجي: هناك الكثير من المعاقين يحتاجون إلى إدخالهم المستشفى لتلقي العلاج أو الإدئ التأهيل، وهذا يتطلب الانفصال عن الأسرة والأصدقاء والمدرسة. ونتيجة لذلك فإن المعاق يتأثر وينعزل عن إلن إنى الآخرين ويتكرر ذلك مع تكرر دخوله المستشفى مما يؤثر على طبيعة علاقته مـع الآخرين مستقبلا. ومن

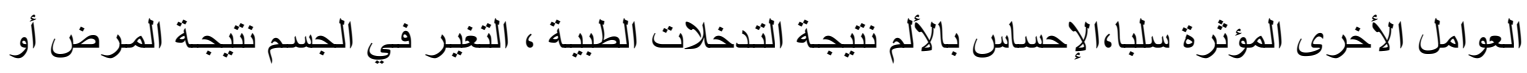
طرق العلاج وفقدانه السيطرة على حركته. لهذا فإن عدم قدرة الأهل على احتواء هذه المشاعر لدى المعاق قد بصيبهم بالقلق و الثعور بالذنب. r- مشكلات خاصة بتفسير طبيعة العجز للمعاق وإعلامه بالخطوات المرتقبة للعلاج والتأهيل: من الأفضل بـل

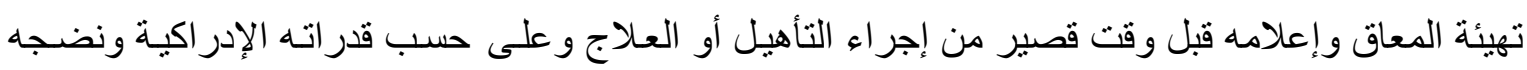
الاجتماعي وذللك لتهيئته للبيئة الجديدة التي سيدخلها. r- مشكلات ترتبط بتربية المعوق إن عدم وجود تقاليد مجتمعية معروفة لطرق تربية الطفل المعاق وانعدام التجارب على الصعيد الثخصي و العائلي يزيد من أعباء رعاية الوالدين، وكذلك عدم توفر در اسـات مؤكدة

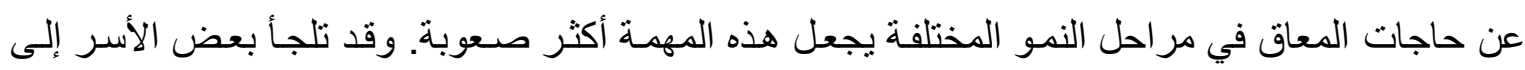

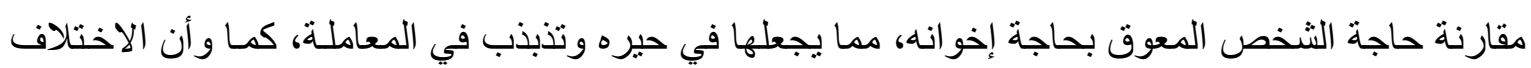
في تطبيق النظام على المعوقين و أنقائهم من حيث الحقوق و الو اجبات و الضو ابط خاصة عندما يمبل الأبوان إلى عدم ردع المعوق حينما يسيء التصرف. قد يؤدي إلى بعض الإشكاليات في الأسرة.

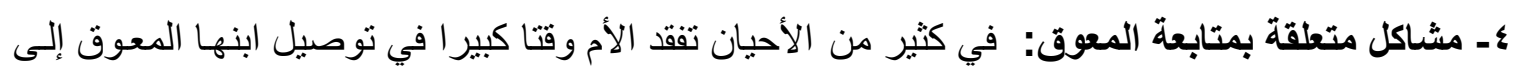

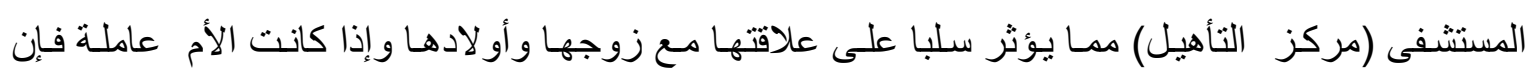
المشكلة تصبح أكبر حيث ان ذلك يستلزم تكر ار غيابها عن العمل. هـ ـ صعوبة التعامل مع المؤثرات الطارئة ان قدرة الأسرة على التعامل مع المؤثرات الطارئـة في حياتها تصبح أكثر صعوبة في ظل وجود شخص معوق. דـ الإجازات والترفيه: ان تخطيط الإجازات وما يتعلق بـأمور الترفيه لكل أفر اد الأسرة يحتاج إلى إعـادة نظر في ظل وجود شخص معوق مما يسبب إرباكا كبير اللأسرة بمجموع أفر ادها. 
V- الأمور الماليـة: الزيـادة في تكاليف العنايـة بالمعاق وتوفير احتياجاته الماديـة، إضـافة إلى تكلفة العـلاج و التأهيل قد لا يكون في مقدور الأسرة توفير جميع تلك المستلزمات ومتطلباتها للفرد المعاق الأمر الذي

يسبب ضغطا إضافيا ومضاعفا عليها.

^- المشكلات النفسية والاجتماعيـة : وهي نظهر على شكل ردود أفعال و اضطر ابات نفسية كردود فعل عند و لادة طفل معاق، وقد أجمعت الدراسات على ان ردود الفعل هذه وما ينتج عنها تتمثل في شكل ضغوط نفسية وآتار سلبية اجتماعية، وهي تتر اوح لدى الو الدين بين الصدمة و النكر ان و الثـعور بالذنب و الخجل و الرفض. ويتضح من خلال ذلك ان نسبة مشاكل المعاقين في المحافظة كغير هم من المعاقين في محافظـات العر اق بلغت . . 1\% لكافة المشاكل ،لان اغلب المشـاكل مجتمعة يعانون منها مـع اسر هم وهم ليس لهم حقوق او واجبات و هم شريحة منسية من قبل المؤسسـات الحكوميـة ومهملين، و اغلب حاجـاتهم لا يحصلون عليها ويو اجهون صعوبات على جميع الاصعدة ومن مختلف شر ائح المجنم.

\section{ثامنا: الاثار الناتبة عن الاعاقة}

اولا: الآثار النفسية : إن السمات أو الخصائص النفسية للمعوقين تشترك أو تتشـابه من حيث بعض الآثار النفسية للإعاقة بشكل عام، كالقلق و التوتر و الانفعال و غير ها من السمات التي تكون عامـة للدى فئات اخرى منهم إلا إنها قد تثميز بسمات نفسية مرضية لا توجد لدى بعض الفئات فحياتهم مجموعة من الحرمان الذي لا يكون موجودا لدى بعض الفئات الأخرى ، وتزداد الإعاقة سو عا مع تقدم العمر، وتزداد الإحباطات التي تعبر عن حالته النفسية بسبب تلك العقبات التي تعترضاه .وهو في هذه الحال إما أن ينسحب وتعتل صحته النفسية ، و إما أن يتجه نحو نفسه كي يعوضها ذلك الحرمان بما تبقى لديه من قدرات.فالمعوق لـه مشكلات و لا بمكن إدماجه في الحياة العامة بشكل فعال إلا بعد معالجة هذه المشكلات، فهو أو لا لديه مشكلة تتمثل في عدم القدرة على الحركة أو ضعفها، او الكلام او السمع وينتج عن هذه المشكلة اخطر المشـاكل الاجتماعيـة، وهي الاعتماد على الآخرين، و هذه نشكل اكبر صـوبة يمكن أن تصـادف المعاق إذ انه سيثـعر بـالنقص وييني صورة سلبية عن نفسـه وسيثـعر بـالقلق والاكتئاب، ومـع تر اكم هذا الثـعور فانها ومن ضمن العمليات اللاشعورية فان ذلك سينعكس علية سلوكيا من عدو انية وانطو اء مما يترتب عليه رفض التو افق مـع مشكلته وتؤثر الإعاقة الجسمية والصحية في الجو انب النفسية والاجتماعية للفرد المعاق و أسرته، وتعتمد شدة هذا التأثير على نوع الإعاقـة وشدتها وعمر الفرد عند الإصـابة بالإعاقة، وكذلك على الظروف الأسرية و المجتمعية التي ينتمي لها الفرد المعـاق، كذللك فان للأسرة دور هـام في التخفيف من معانـاة الفرد المعاق جسميا وصحيا إذا وفرت الأسرة الدعم والثقبل للفرد المعاق أو إنها قد تكون مصدر الهذه المعاناة إذا لم توفر

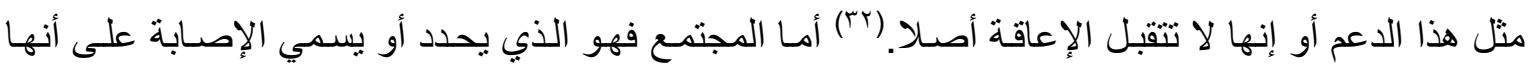
إعاقة بسبب ما تصنع من قيود على الفرد المعاق، أو بتفسيرات المجتمع لمدى الفروق بين أفراده مما يؤثر على نمو الفرد وتكيفه الاجتماعي ومن هنا فان هناك اختلافات في حياة الأفر اد المعوقين في المجتمع و التي تعتمد في الأساس على استجابة المجتمع وتوقعاته .لذلك فان المشكلات التي يعاني منها المعوقون جسميا وصحيا ليست بسبب طبيعـة الإعاقـة فحسب وإنمـا بسبب نظرة المجتمع نحو هم والمتمثلة في العقبات التي 
يضعها المجتمع أو التسـهيلات التي يوفرها للمعوقين أنفسهم .لذلك فالعوامل التي تنؤثر في الجانب النفسي كثيرة إلا إن كل فرد معوق يعتبر منفردا فيما يعايشه من خبرات تنعكس بالتالي على تكيفه مع المجتمع. ثانيا: الآثار الاقتصادية ا ـ التمل الكثير من نفقات العلاج. r. انقطاع الدخل أو انخفاضه وبروز الأعباء على الاسرة. ثالثا: الآثار الاجتماعية ا ـ المشكلات الأسرية: حيث الثعور بالذنب وإعاقة الفرد تقلل من توازن الأسرة وتماسكها. r. المشكلات الترويحية (عدم الاستمتاع بوقت الفراغ . ..) .

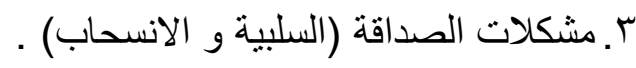
ع. مشكلات العمل ( ترك العمل أو تغييرهو و عدم القدرة على القيام به) . رابعا: الآثار التعليمية

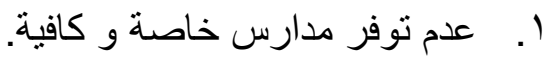
r. الآثار النفسية السلبية للإلحاق الطفل المعوق بالمدارس العادية.

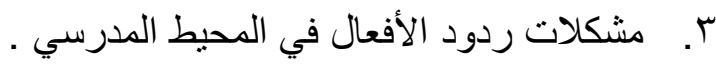
ع. ـتؤثر بعض العاهات على القدرة التعليمية و المعرفة للمعوق.

\section{الاستنتتاجات والاقتزمات}

الاستنتاجات

ا - ان اهمية البيانات المتعلقة عن اعداد المعوقين كونها المؤشر الحقيقي الذي يكثف حجم المشكلة والتي تستند عليها كافـة البر امج و الخدمات اللاحقة وتسهل وضـع الخطط والبر امج الوطنيـة التي تخدم المخطط المركزي ومتخذ القرار ، تكمن بمعرفة حجم المعوقين ونسبتهم الى حجم السكان، حيث لا تعكس البيانات

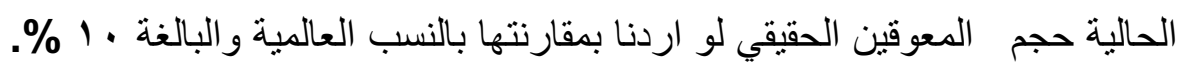

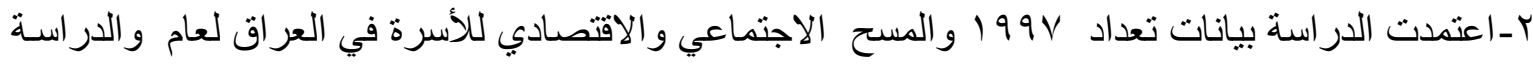

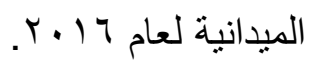

ז-للعو امل الجغر افية سواء كانت طبيعية او بشرية تأثثرات على المعوقين ، اذ من المككن ان تؤثر العوامل الطبيعية ولكن بنسبة بسيطة جداً ، اذ تؤدي حوادث السير و التي تزيد خلال فصل الثتاء الى حدوث البعض من حالات العوق ، بالإضافة الى صعوبة انتقال الاشخاص المعوقين من مكان الى اخر اثناء سقوط الامطلار وزيادة كميات الطين والأوحال في شوارع المحافظة ، و التي تعاني من شبكة طرق أغلبها رديئة ومعظمها طرق ترابية غير معبدة ، بالإضـافة الى زيادة التشنجات و التقلصـات والأوجاع بسبب الحرارة او البرودة و الرطوبة ـ اما العوامل البشرية التي تؤثر على هذه الثريحة من المجتمع فهي تتمثل بالعوامل الاقتصـادية و الاجتماعية و الصحية و الثقافية . 
ع- - يعاني الأفراد ذوو الإعاقة معدلات فقر أعلى بالمقارنـة مـع غير ذوي الإعاقة، وعلى الاغلب يتعرض ذوو الإعاقة والعائلات التي في أفر ادها شخص معوق الى معدلات أعلى من الحرمـان (ومنها عدم تـأمين الغذاء، و المسكن السيئ، مع صعوبة الحصول على الرعايـة الصحية أو تعذر ذللك، كذلك تزداد الكلفة التي يتحملها ذوو الإعاقة بسبب ما يحتاجون إليه من دعم شخصي أو رعاية طبية أو أجهزة مساعدة). هـ ـ ورغم تطور الحركة العمر انيـة إلا ان القليل من البنايـات تم فيها مر اعـاة حاجـة المعوقين لاستخدامها ، و اغلب المباني الخاصة والحكومية لا تتمتع بالمو اصفات الضـرورية لتمكين المعوقين من ارتيادهـا بسهولة ويسر ، فبعض المباني العامـة حتى وان تمكن المعوق من الوصـول الىى أبي طابق فيها فانهـ يو اجـه مشكلة تتعلق باستخدامه للمر افق الصحية فيها نتيجة لضيق مساحتها و عدم ملائمتها لاستخدامه . T-ولقد أوضحت نتائج الدر اسـات أن الطلاب المعوقين بدرجة منوسطة وشديدة يمكن أن يحققوا مستويات أفضل من التحصيل والمخرجات التربوية في الوضع التربوي العام. V- - ان نسبة المعاقين بين الذكور اعلى من الاناث ، اذ بلغت نسبة الذكور (10,09\%) من مجموع المعاقين ، بينما بلغت نسبة الاناث ( ع, • § \%) من مجموع المعاقين.

A- هنالك تباين في النسب المئوية لكل فئة عمرية من مجموع المعاقين، اذ تبين ان اعلى النسب للمعاقين قد

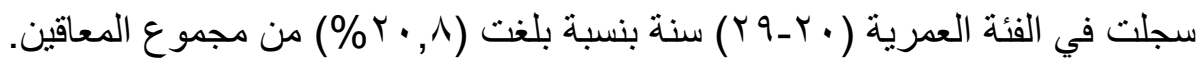

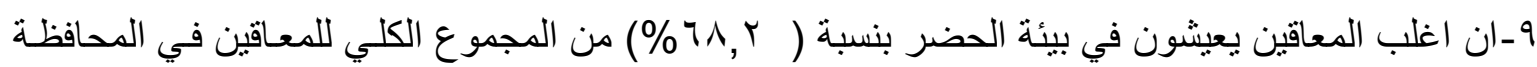
، ويعزى ذلك الى توفر مختلف الخدمات التي يحتاجونها والتي تسـل لهم مسيرة الحياة وخاصـة من ذوي الاحتياجات الخاصة و الذين يتطلب سكنهم ان يكون في الحضر .

• 1- ان نسبة الاعاقة الحركية في محافظة واسط قد بلغت (ع, ( (\%) من مجموع المعاقين الكلي ولمختلف

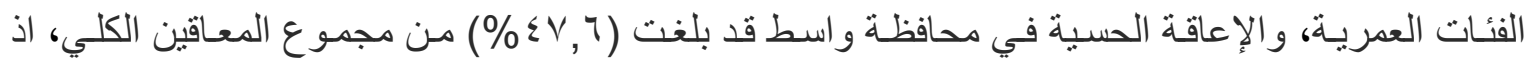

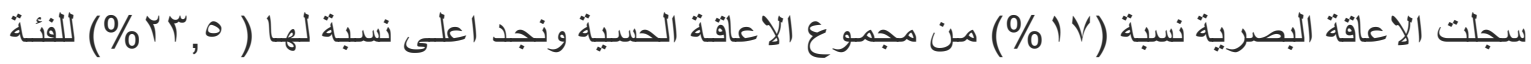
العمرية ( • ــهـ) سنة ويعود سبب ذلك الى الاصـابة بأمر اض العيون المختلفة والتي تؤدي الى فقدان البصر نتيجة لكبر السن. امـا نسبة الاعاقة الذهنية فقد بلغت ( •\%\%) من المجموع الكلي للمعاقين ـ وان نسبة الاعاقة العقلية بلغت (9\%) من المجموع الكلي للمعاقين ولمختلف الفئات العمريـة ، اذ نجد اعلى نسبة

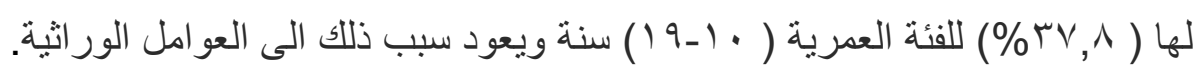
11 - اتضح ان سبب الاعاقة في المحافظة يعود للكثير من هذه الاسباب الواردة ، وقد سـاهمت الحروب و العمليات الار هابيـة في زيادة نسبة الاعاقة في العراق عامـة و المحافظـة خاصـة ، اذ سجلت نسب اسباب الاعاقة ولكل فئة عمرية .

با - يواجـه المعوقون الكثير من الضـغوطات والتوترات خـلال محساو لاتهم التكيف والتعايش مـع بيئتهم المحيطة بهم ، ويعانون الكثير من المشكلات النفسية والاجتماعيـة والاقتصـادية خـلال تعاملهم مـع اسر هم وأقاربهم ومؤسسات المجتمع المختلفة. 
با - إن السمات أو الخصائص النفسية للمعوقين تشترك أو تتشـابه من حيث بعض الآثار النفسية للإعاقة بشكل عام، كالقلق والتوتر و الانفعال وغير ها من السمات التي تكون عامة لدى فئات اخرى منهم إلا إنها قد تتميز بسمات نفسية مرضية لا توجد لاى بعض الفئات فحياتهر مجمو عة من الحرمان الذي لا يكون موجودا

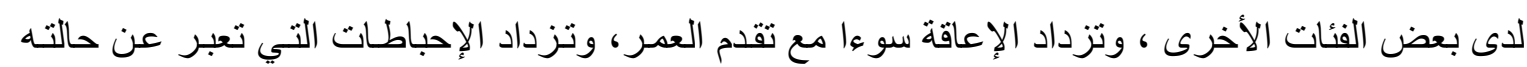
النفسية بسبب تلك العقبات التي تعترضه

المقترحات

1 - ضرورة وضع استر اتيجيات وطنية خاصة بهذه الفئة السكانية ترسم اجر اءات مسار عمل العناية بها. r - در اسة امكانيـة تتكيل هيئة وطنيـة لتنظيم مسـار ات عمل الرعايـة و العنايـة بـالمعوقين من خلال اصدار القو انين و التشريعات الخاصة بذلك.

r- تنشيط دور المجتمع للمساهمة في تقديم الخدمات الاجتماعية لتعزيز وتعضيد جهد الدولة بمـا يعزز القيم الدينية و الأعر اف الاجتماعية، وان نأخذ على عاتقها التنسيق والتعاون الاكبر مع وزارات الدولة ذات العلاقة و الاستفادة من المنظمات الغير الحكومية العالمية لإفادة هذه الفئة .

عـ شمول اكبر عدد من المعوقين بخدمات التأهيل والوصول بتلك الخدمات الى منـاطق جديدة . من خـلال التو عية بأهمية العمل التطوعي لإشر الك المجتمع المدني في خدمة المعوقين ه ـ ان تضع وز ارة العمل والثؤون الاجتماعية ضمن اولوياتها للسنوات المقبلة تقديم الخدمات المقررة لكافة المعوقين و عدم الاقتصار على المعوقين داخل الوحدات العائدة الى دائرة الرعايـة الاجتماعيـة وتطوير هذه الخدمات بما يتناسب والتوجهات العالمية في هذا المجال مع تعميق دور الاقتر اض لتشغيل المعوقين. דـ التحرك نحو تحسين احصاءات الاعاقة من حيث دقة المعلومـات وتوفرهـا و تخصيص مو ارد الميز انيـة الملائمة من اجل جمع بيانات الاعاقة بشكل منظم وتحليلها ونشر ها. V- وضع بر امج وقائية وبر امج للكثف المبكر و التشخيص مـع التو عيـة والتثقيف الصحي في مجال الاعاقـة وتامين الوسائل الكفيلة بالتدخل المبكر و المتخصص. و إلز ام الو الدين بالتصريح بالإعاقة عن طريق مر اكز الر عاية الصحية للام و الطفل . A- التوسع في فتح مر اكز تشخيص العوق ليضم عددا كافيا من كافة الاختصاصـات ، حيث ان التعرف المبكر على الكثير من انواع العوق يعتبر امر اضروريا جدا وذللك لإمكانية التحسن عن طريق العلاج الطبي

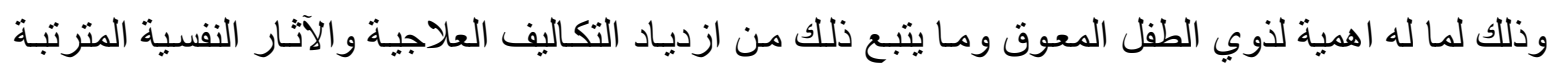
على المعوق وذويه عند اهمال الناحية العلاجية.

9 - يجب ان تشكل الاجر اءات الوقائية الاولية جزءا هامـا من جميع البر امج الوطنية الصحية و التعليمية و البيئية وان تنظم في مر اكز الرعاية الصحية للام و الطفل وفي قاعات مخصصـة محاضر ات للام تتضمن لتصن كافة الارشنادات الوقائية لتجنب حدوث العوق للطفل ابتداء من فترة مـا قبل الحمل، و الحمل و الوضـع و الـى فترة الطفولة المبكرة وان تشمل كذلك التخطيط الاسري ومكافحة الامر اض المعديـة والصحة البيئية ومنع 
التلوث، وتوعيتهم بأثر الاصـابات المتعلقة بالنشـاطات الترفيهية وأخطار الالعـاب الرياضية والتوعية بـا

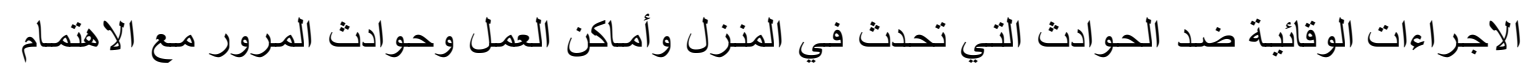
بالتو عية وتعزيز الاجر اءات الخاصة بر عاية الصحة العقلية في المجتمع.

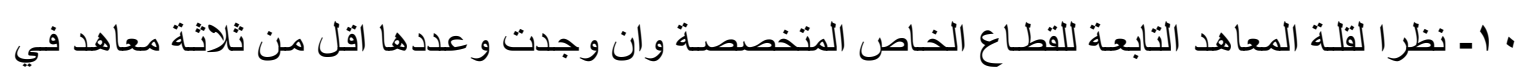
محافظة واسط فهي قليلة جدا فيقترح تشجيع القطاع الخـاص على فتح المعاهد التخصصية وان يراعى وهى وهي

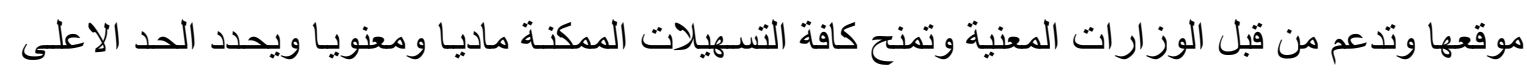
لأجور كل طالب ، مع انشاء مر اكز تخصصية مزودة بمعدات وأجهزة حديثة، ومعلمين ومدربين مؤهلين تكون مرجعا لإسناد جميع تلك المعاهد و الاستعانة بذوي الاختصاص و الحاصلين على شهادات تخصصية

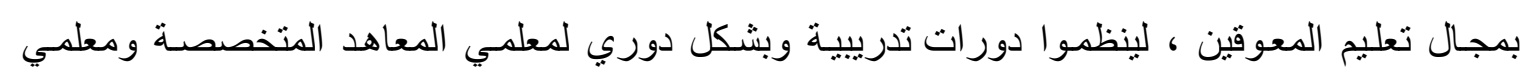
الصفوف الخاصة في وزارة التربية. 1 ا ـ تخصيص ايام معينة لكل نوع عوق تجرى فيه الفحوصات الدورية وينم اعطاء العلاج كل وحسب نوع عوقه مع تدريب ذوي الاطفال المعوقين لكيفية العناية بالطفل المعوق حسب نوع عوقه. r ا ـ نشر خدمة المعوقين في المناطق النائية والريفية عن طريق الاستعانة بالمر اكز الصحية والجمعيات

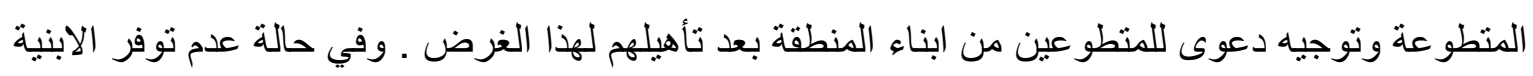
المتخصصة تخصص سيار ات خاصة متنقلة تحوي كافة الاجهزة العلاجية.

\section{هوامش البمث}

* تم دمج بيانات الوحدات الادارية الاخرى في المحافظة ( النواحي ) ضمن القضاء التابع له .

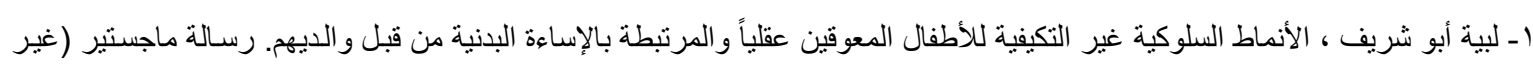

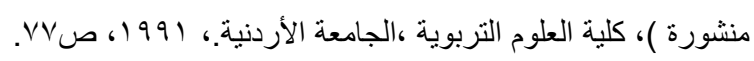
r- اسماء ملكاوي ، خصائص الأطفال ذوي الأمر اض المزمنة واحتياجاتهم الاجتماعية ، رسـالة ماجستير (غير منشورة) ، الجامعة الأردنية، . 79 (1994 ا - ذياب البداينة ، الخصائص الاجتماعية والإعاقة .مؤتة للأبحاث والدر اسـات ،السلسلة (أ) من مجلة العلوم الاجتماعية والإنسانية، المجلد

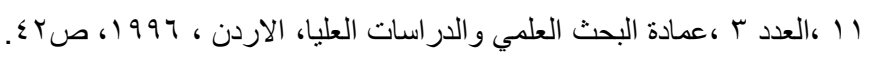

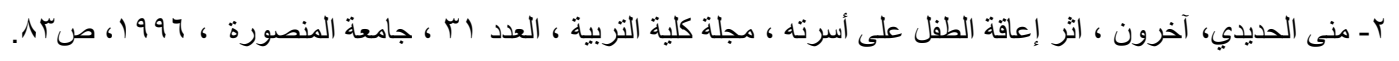

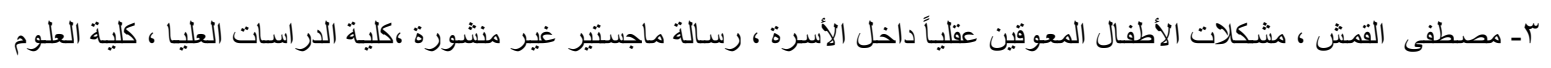

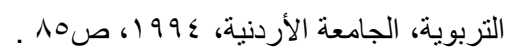

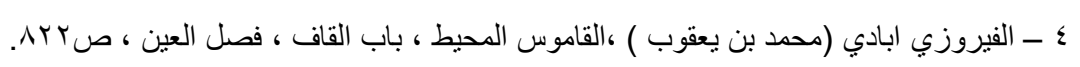

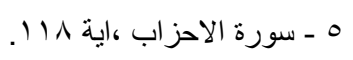

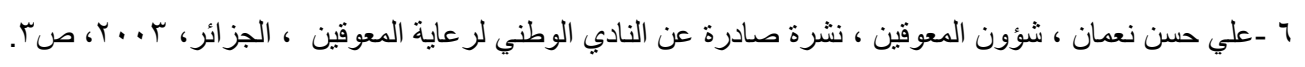

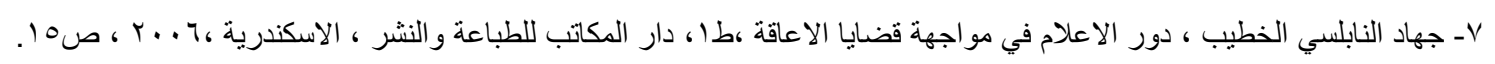

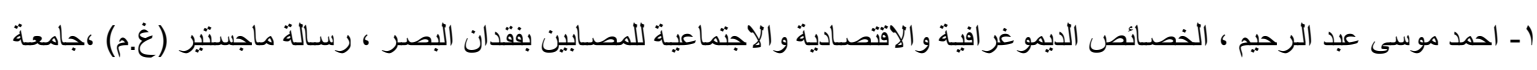

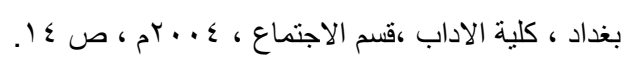

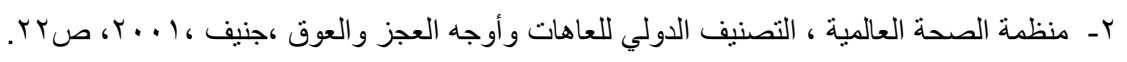

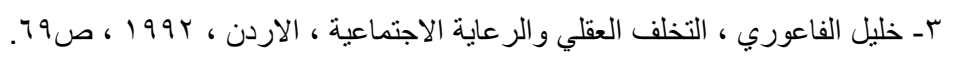

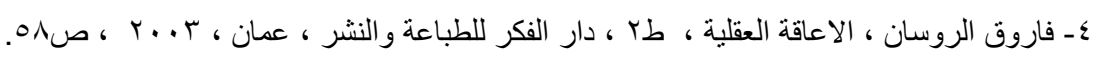




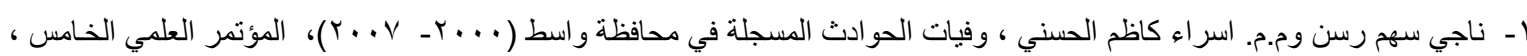

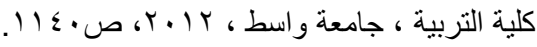

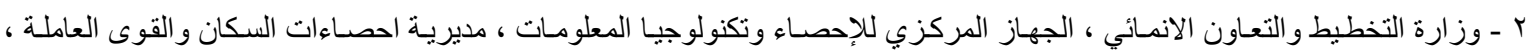

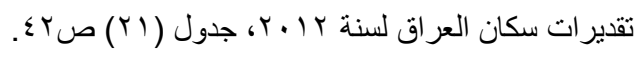

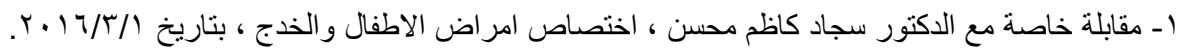
* ينم استخر اج معامل ارتباط سبيرمان للرتب : من المعادلة التالية

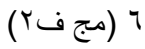

ر= 1 - ------------------ ، حيث ان ر= معامل الارتباط ، ف = الفرق بين ترتيب الافراد على المتغير الاول

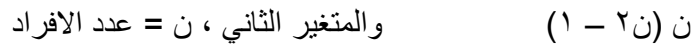

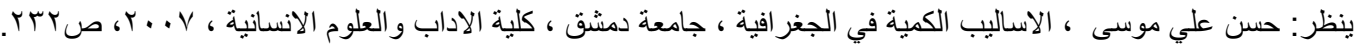

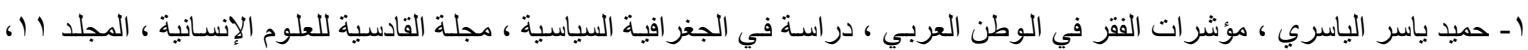

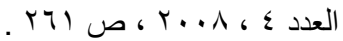

Y- المصدر نفسه ، ص • דץ .

r- وزارة التخطيط و التعاون الانمائي ، الجهاز المركزي للإحصـاء وتكنولوجيـا المعلومـات ، مديريـة إحصـاءات احوال المعيشـة ، حزيران ، E * ت تم استخر اج معامل الارتباط

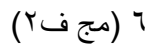

، حيث ان ر= معامل الارتباط ، ف = الفرق بين ترتيب الافراد على المتغير الاول $-1=$

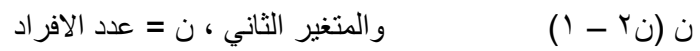

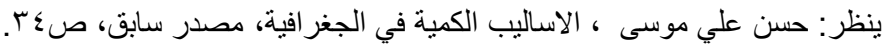

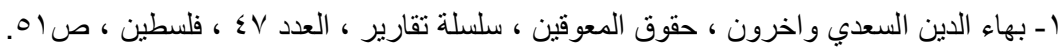
r- سها وليد مصطفى ، الابعاد الجغر افية لمرض التدرن الرئوي في محافظة البصرة ، رسالة ماجستير غير منشورة ، جامعة البصرة ، كلية

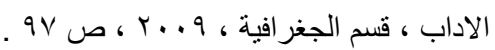
r- حسين عبد الحميد رشوان ، اثر المتغير ات الاجتماعية في الطب والامر اض ، دراسة في علم الاجتماع الطبي ،المكتب الجامعي الحديث ،

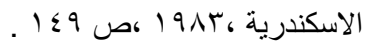

\begin{tabular}{|c|c|c|}
\hline 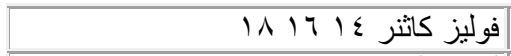 & كرسي كهربائي & 1 \\
\hline |أكياس أدرار سعة . ... (مل & كرسي متحرك اعتيادي & r \\
\hline أكياس أدرار سعه ...0مل & كرسي متحرك للأطفال & r \\
\hline مجمو عة قسطرة منقطعة & كرسي منحرك ذو مسند عالي & $\varepsilon$ \\
\hline كوندوم لجمع الإدرار (للكبار) & كرسي متحرك للمبتورين & 0 \\
\hline كوندوم لجمع الإدرار (للأطفال) & كرسي يدار بيد واحدة & 7 \\
\hline |فوليز كاثنر حجم ^ ، . 1 & كرسي حمام متحرك & v \\
\hline قو اعد كولوستومي حجم 0؛ ، & كرسي تو اليت ثابت & $\wedge$ \\
\hline | اكياس كولوستومي & عكازه ثلاثية & 9 \\
\hline ج8 & \multirow[t]{2}{*}{ عكازه رباعية } & \multirow[t]{2}{*}{1.} \\
\hline $\begin{array}{r}\text { Active apparatus for Erectile } \\
\text { dysfunction }\end{array}$ & & \\
\hline & عكازه مرفقيه & 11 \\
\hline & عكازه أبطيه مع مسند للساعد & IT \\
\hline & مشاية متحركة & Ir \\
\hline
\end{tabular}

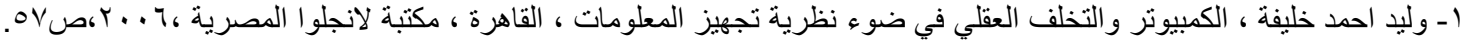

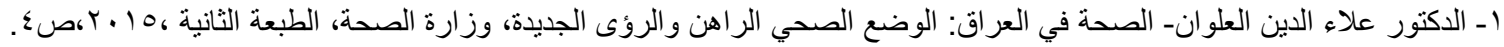
* اهم الاجهزة و العلاجات التي يحتاجها المعاقين والتي لا تتوفر في مر اكز التأهيل للمعاقين والتي يلجأ الى شر اءها من الاسواق: 


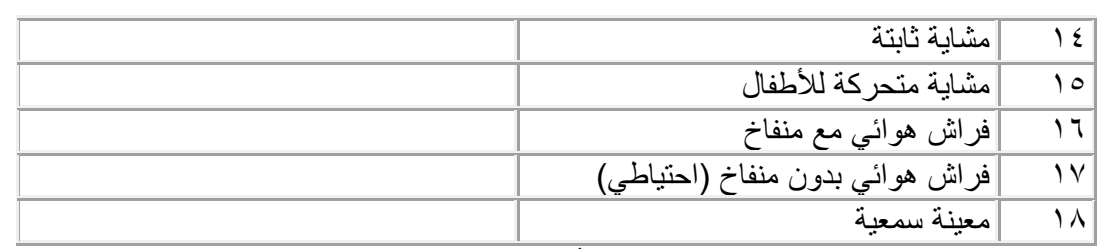

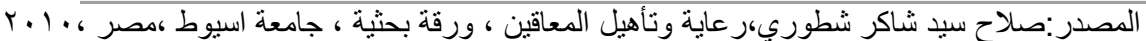

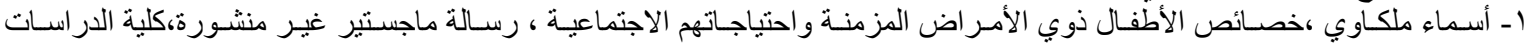

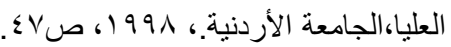

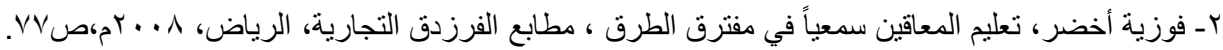

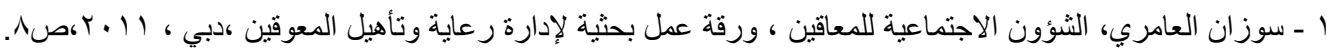

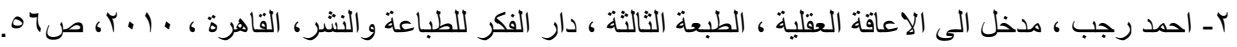

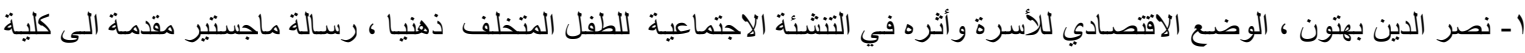

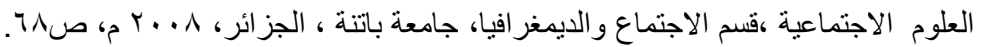
* الحر ائق، العطليات الار هابية ، المشاجرات، السقوط من مكان مرتفع ، اللعب بالأدوات الجارحة ، الصعق الكهربائي ...الخ

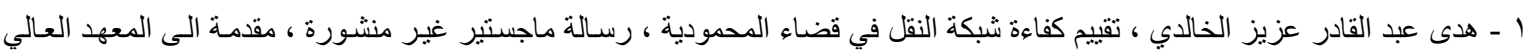

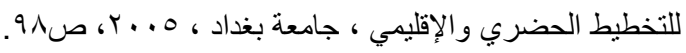

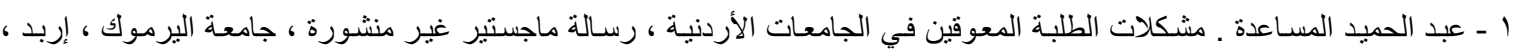

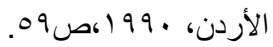
r - محمد سـمي حرز الله، مشكلات التكيف التي يواجهها المعوقون حركياً، رسالة ماجستير غير منشورة ، جامعة اليرموك ، إربد ،

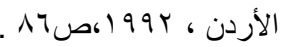
ا ـ عبد العزيز عبدات ، الاثار النفسية والاجتماعيـة للإعاقة على أخوة الاشخاص المعاقين : مكتبة الثـارقة للخدمات الانسـانية،الامارات، .VV ا - مروان عبد المجيد ابر اهيم ، الرعاية الاجتماعية للفئات الخاصة تربوياً نفسياً رياضياً و تأهيلياً، مؤسسة الوراق للنشر

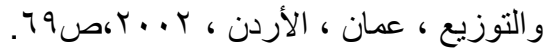

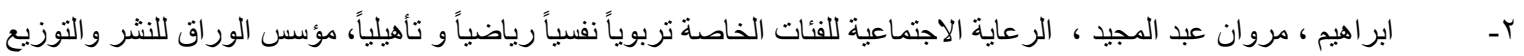

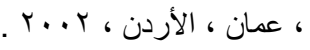

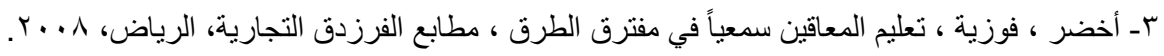

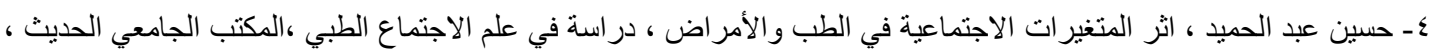

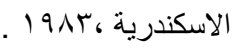

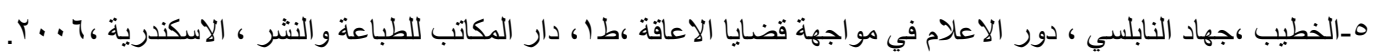

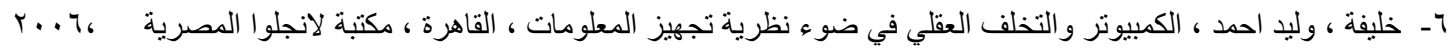

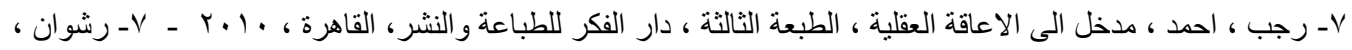

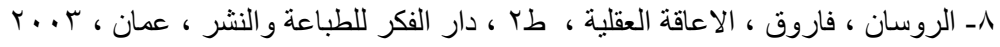

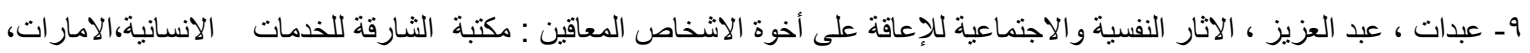


ثانيا: الرسائل والاطاريح الجامعية

ا-أبو شريف، لبية ، الأنماط السلوكية غير التكيفية للأطفال المعوقين عقلياً والمرتبطة بالإساءة البدنية من قبل والديهم. رسالة ماجستير (غير

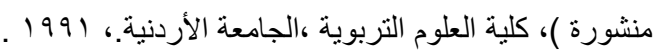
ץ- بهتون ، نصر الدين ، الوضع الاقتصادي للأسرة وأثره في التنشئة الاجتماعية للطفل المتخلف ذهنيا ، رسالة ماجستير مقدمة الى كلية

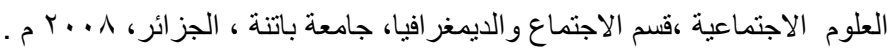
ז- حرز الله ، محمد سامي ، مشكلات التكيف التي يواجهها المعوقون حركياً، رسالة ماجستير غير منشورة ، جامعة اليرموك ، إربد ،

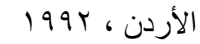
ع - الخالدي ، هدى عبد القادر عزيز ، تقييم كفاءة شبكة النقل في قضاء المحمودية ، رسالة ماجستير غير منشورة ، مقدمة الى المعهد العالي

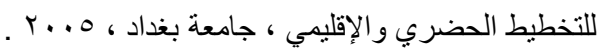
ــ القمش ، مصطفى ، مشكلات الأطفال المعوقين عقلياً داخل الأسرة ، رسالة ماجستير غبر منشورة ،كلية الدراسات العليا ، كلية العلوم

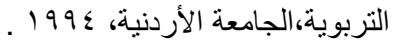

7 ـ المساعدة ،عبد الحميد ـ مشكلات الطلبة المعوقين في الجامعات الأردنية ، رسالة ماجستير غير منشورة ، جامعة اليرموك ، إربد ، الأردن، . 199.

V- مصطفى ،سها وليد ، الابعاد الجغر افية لمرض التدرن الرئوي في محافظة البصرة ، رسالة ماجستير غير منشورة ، جامعة البصرة ، كلية

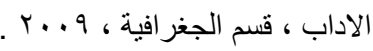

^- ملكاوي، أسماء ،خصائص الأطفال ذوي الأمر اض المزمنة واحتياجاتهم الاجتماعية ، رسالة ماجستير غير منشورة،كلية الدراسات

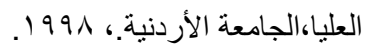
ثالثا: البحوث و الدوريات

ا ـ حميد ياسر الباسري ، مؤشرات الفقر في الوطن العربي ، دراسة في الجغرافية السياسية ، مجلة القادسية للعلوم الإنسانية ، المجلد 1ل،

العدد ؛ ، ^ ... . .

r- ذياب البداينة ، الخصائص الاجتماعية والإعاقة .مؤتة للأبحاث و الدراسات ،السلسلة (أ) من مجلة العلوم الاجتماعية والإنسانية، المجلد

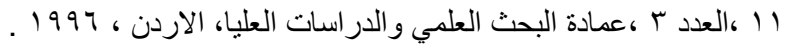

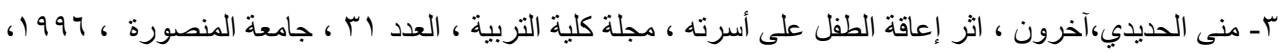

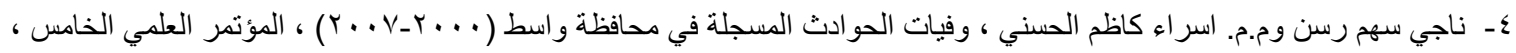

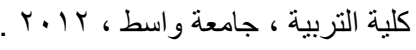
رابعا: النشرات

Iـ السعدي ، بهاء الدين واخرون ، حقوق المعوقين ، سلسلة تقارير ، العدد V؟ ، فلسطين .

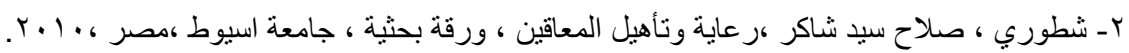

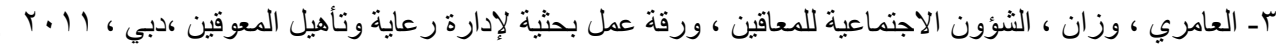

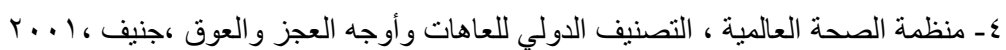

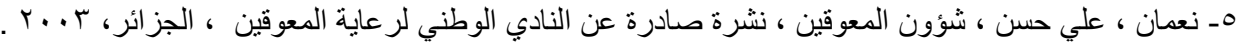
خامسا: الدوائر الرسمية ا ـ وزارة التخطيط والتعاون الانمائي ، الجهاز المركزي للإحصاء وتكنولوجيا المعلومات ، مديرية إحصاءات احوال المعيشة ، حزيران ، . r. I Y- وزارة التخطيط ، الجهاز المركزي للإحصاء ، نتائج التعداد العام للسكان لسنة \99 19، الجزء الخاص بمحافظة واسط ، 991 (،جدول

r- وزارة التخطيط والتعاون الانمائي ، الجهاز المركزي للإحصاء وتكنولوجيا المعلومات ، مديرية احصاءات السكان والقوى العاملة ،

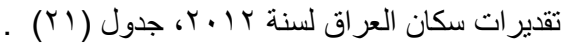

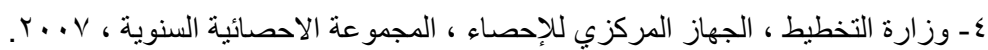
0- زارة الصحة ، دائرة صحة واسط ، شعبة الاحصاء، بيانات غير منشورة ، 10 ــ ب. 
المقابلات

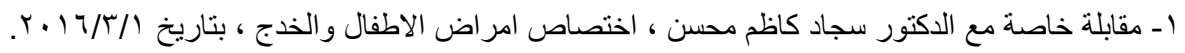

\section{همق (1) استمارة استبيان}

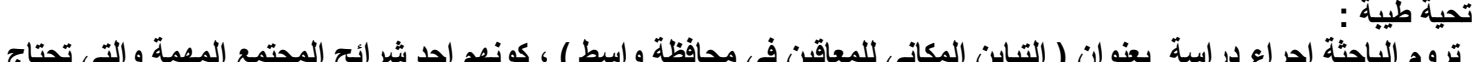

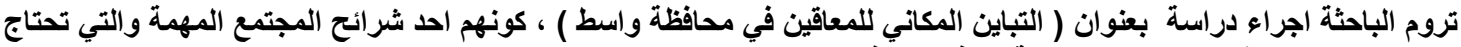

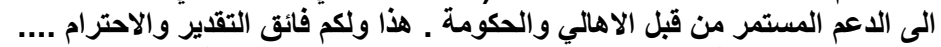

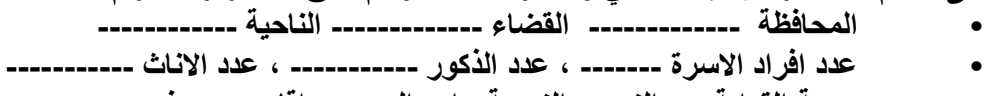

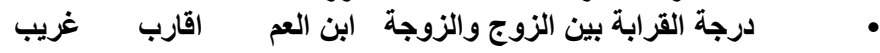

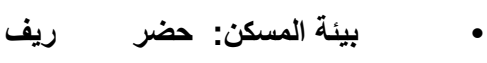

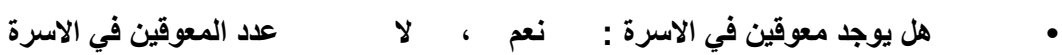

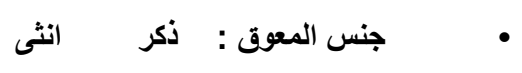

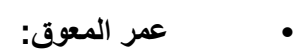

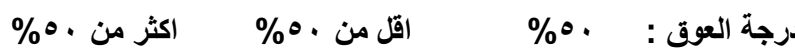

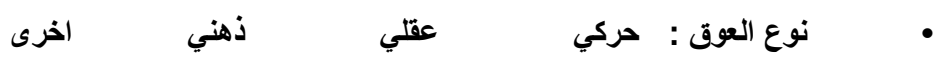

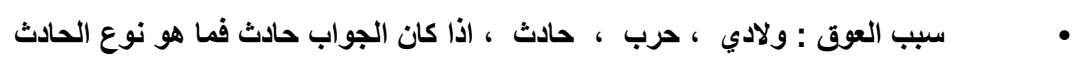

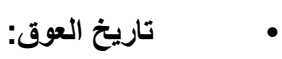
ماهي الاعمال التي يجيد ها الشخص المعوق: • المستوى التعليمي للمعاق : امي ، ابتائي ، متوسط ، اعدادي ، بكلوريوس ، اخرى هل يتقاضى المعوق راتب شهري : نعم ل الا اذا كان الجواب نعم ماهي الجهة الماتحة للراتب:

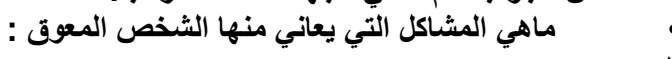

اهم المشاكل التي تعاني منها الاسرة التي لايها شخص معوق :

ماهو الثيء الذي تحتاج ان تقدمه الدولة للشخص المعوق : 